\title{
Measuring substance-related disorders using Canadian administrative health databanks: interprovincial comparisons of recorded diagnostic rates, incidence proportions and mortality rate ratios
}

Christophe Huỳnh ${ }^{1-5}$, Steve Kisely ${ }^{6-7}$, Louis Rochette ${ }^{5}$, Éric Pelletier ${ }^{5}$, Kenneth B.

Morrison $^{8}$, Shelley Li ${ }^{8}$, Gareth Hopkin ${ }^{9-10}$, Mark Smith ${ }^{11}$, Charles Burchill ${ }^{11}$, Elizabeth Lin $^{12-14}$, Mark Asbridge ${ }^{6}$, Didier Jutras-Aswad ${ }^{1,2,15}$, Alain Lesage $e^{1,2,5,16}$

1. University Institute on Addictions, CIUSSS du Centre-Sud-de-1'Île-de-Montréal, Montréal, Québec, Québec

2. Department of Psychiatry and Addiction, University of Montréal, Montréal, Québec, Canada

3. School of Psychoeducation, University of Montréal, Montréal, Québec, Canada

4. Recherche et intervention sur les substances psychoactives - Québec, TroisRivières, Québec, Canada

5. Institut national de santé publique du Québec, Québec, Québec, Canada

6. Department of Community Health and Epidemiology, Dalhousie University, Halifax, Nova Scotia, Canada

7. School of Medicine, University of Queensland, Queensland, Australia

8. Alberta Health, Edmonton, Alberta, Canada

9. Institute of Health Economics \& University of Alberta, Edmonton, Alberta, Canada

10. Health Technology Wales, NHS Wales/GIG Cymru, Cardiff, Wales, United Kingdom 
11. Manitoba Centre for Health Policy, Rady Faculty of Health Sciences, University of Manitoba, Winnipeg, Manitoba, Canada

12. Centre for Addiction \& Mental Health, Toronto, Ontario, Canada

13. Department of Psychiatry, University of Toronto, Toronto, Ontario, Canada

14. ICES, Toronto, Ontario, Canada

15. Research Centre, Centre hospitalier de l'Université de Montréal, Montreal, Quebec, Canada

16. Research Centre of the Montréal Mental Health University Institute, Montréal, Québec, Canada

Corresponding author: Christophe Huỳnh, Ph.D.

University Institute on Addictions

CIUSSS du Centre-Sud-de-l'Île-de-Montréal

950, rue de Louvain Est

Montréal (Québec) H2M 2E8

Phone : +1 (514) 385-1232 ext. 3203

email : christophe.huynh.ccsmtl@ssss.gouv.qc.ca

Word count (abstract, max: 300): 298

Word count (body text: $\max$ 3500): 3507

Number of tables: 2

Number of figures: 3 


\section{ABSTRACT}

Context: Assessing temporal changes in the recorded diagnostic rates, incidence proportions and health outcomes of substance-related disorders (SRD) can inform public health policymakers in reducing harms associated with alcohol and other drugs. Objective: To report the annual and cumulative recorded diagnostic rates and incidence proportions of SRD, as well as mortality rate ratios (MRR) by cause of death among this group in Canada, according to their province of residence. Methods: Analyses were performed on linked administrative health databases (physician claims, hospitalizations, vital statistics) in five Canadian provinces (Alberta, Manitoba, Ontario, Québec, and Nova Scotia). Canadians 12 years and older and registered for their provincial healthcare coverage were included. The International Classification of Diseases (ICD-9 or -10 codes) was used for case identification of SRD from April 2001 to March 2018. Results: During the study period, the annual recorded SRD diagnostic rates increased in Alberta (2001-02: 8.0\%; 2017-18: 12.8\%o), Ontario (2001-02: 11.5\%o; 2017-18: 14.4\%o), and Nova Scotia (2001-02: 6.4\%o; 2017-18: 12.7\%o), but remained stable in Manitoba (2001-02: 5.5\%; 2017-18: 5.4\%o) and Québec (2001-02 and 2017-18: 7.5\%o). Cumulative recorded SRD diagnostic rates increased steadily for all provinces. Recorded incidence proportions increased significantly in Alberta (200102: 4.5\%o; 2017-18: 5.0\%o) and Nova Scotia (2001-02: 3.3\%o; 2017-18: 3.8\%o), but significantly decreased in Ontario (2001-02: 6.2\%o; 2017-18: 4.7\%o), Québec (2001-02: 
4.1\%o; 2017-18: 3.2\%o) and Manitoba (2001-02: 2.7\%o; 2017-18: 2.0\%o). For almost all causes of deaths, a higher MRR was found among individuals with recorded SRD than in the general population. The causes of death in 2015-2016 with the highest MRR for SRD individuals were SRD, suicide, and non-suicide trauma in Alberta, Ontario, Manitoba, and Québec. Discussion: Linked administrative health databases covering almost the entire population can be useful to monitor medical service trends of SRD and, therefore, guide health services planning in Canadian provinces.

MeSH Keywords: Alcohol-Related Disorders, Substance-Related Disorders, Healthcare

Administrative Claims, International Classification of Diseases, Premature Mortality, Canada 


\section{INTRODUCTION}

In 2017, substance-related problems cost Canadians around $\$ 46$ billion, with alcohol being the major contributor at $\$ 16.6$ billion per year. ${ }^{1}$ Administrative health databases (AHD) are critical to monitor substance-related disorders (SRD) as recorded in the Canadian medical system and to provide information useful for shaping health policy responses. ${ }^{2,3}$ AHD can complement epidemiological surveys because they have the advantages of covering nearly the entire population and are routinely updated. ${ }^{2,4}$

Substance use encompasses a wide range of phenomena, from use that does not cause harm to SRD. ${ }^{5} \mathrm{SRD}$ can further be divided into three categories: substance use disorders (SUD: abuse and dependence), substance-induced disorders (withdrawal, secondary psychoses, alcohol cirrhosis, etc.), and acute intoxication (bad trips, ethylic comas, etc.). ${ }^{5}$ This categorization takes into account the 9th and 10th revision of the International Classification of Diseases (ICD) and the 4th and 5th edition of the Diagnostic and Statistical Manual of Mental Disorders. ${ }^{6-9}$

The most recent epidemiological survey in 2017 found that $4.1 \%$ of Canadians reported some form of non-alcohol substance-related harm, in the previous year. British Columbia had the highest rate $(6.6 \%)$ and Manitoba $(2.1 \%)$ the lowest. ${ }^{10}$ The most recent national epidemiological data for specific SUD diagnoses (2012) noted that $21.6 \%$ of 
Canadians met DSM-IV diagnostic criteria for lifetime SUD (alcohol and drugs) and 4.4\% for annual SUD. Interprovincial differences were also noted, with the lowest annual (3.9\%) and lifetime (17.8\%) prevalence rates in Quebec, and the highest in the Prairie provinces (5.2\% and $28.5 \%$ respectively). ${ }^{11}$ These interprovincial differences highlight the need for policymakers to obtain specific regional data.

Previous international studies consistently report higher rates of mortality among individuals with SRD compared to the general population, although there are variations in causes of death as a result of differences in the method or timing of data collection. ${ }^{12-19}$ There is less information for Canada, particularly for the mortality rate gaps between individuals with and without recorded SRD. To address this gap, we compared temporal trends of recorded SRD diagnoses, recorded incidence proportions and mortality rate ratios by cause of death among Canadians by their province of residence. While this research could not capture all cases of SRD, the aim was to allow a better understanding of gaps in data availability that might be barriers to a potential strong SRD surveillance system in Canada. These data could be relevant to other jurisdictions with similar AHD in informing public health. 


\section{METHODS}

\section{Setting}

All Canadian residents can receive free inpatient or outpatient treatment within the public health system, managed at the provincial level. Information concerning diagnoses and medical services is routinely compiled in health insurance registries that cover nearly the entire population of each province, and data can be linked using unique personal identifiers. ${ }^{20}$ As the majority of clinical payments for general practitioners and medical specialists are billed using a fee-for-service system (94\% in 2001-2002; 73\% in 2017-2018), most medical

contacts are therefore captured by AHDs. ${ }^{21,22}$ For instance, about $99 \%$ of physicians in Ontario and Québec, 91\% in Alberta, 90\% in Manitoba and 63\% in Nova Scotia received at least one payment through fee-for-service in $2017-2018 .^{22}$

\section{Study population}

This study included all residents aged 12 years and older of Alberta, Manitoba, Ontario, Québec, and Nova Scotia who were registered for their provincial health insurance plan. This excludes individuals who are not permanent residents of the province (visitors, exchange students) or absent from their residential province for at least half of the year. In some provinces, specific populations (e.g. refugees, inmates, military officers) are also excluded. Five provinces were chosen to represent different regions of Canada (Western 
Canada/Prairies: Alberta and Manitoba; Central Canada: Ontario and Québec, Atlantic/Eastern Canada: Nova Scotia). This study, therefore, covered $79.2 \%$ of the total population of Canada $(35,151,725$ inhabitants $) .{ }^{23}$

\section{Data sources}

All administrative data were linked using an encrypted unique identifier. Diagnoses from the physician billing databases were coded using ICD-9-CM in Alberta and Manitoba, and ICD-9 in Ontario, Québec and Nova Scotia. ${ }^{24,25}$ Hospitalization discharge databases were updated from ICD-9 to ICD-10-CA diagnostic codes at a different pace across provinces: 2001 in Nova Scotia, 2002 in Alberta and Ontario, 2004 in Manitoba, and 2006 in Quebec; all allowed a five-digit coding and 25 codes per claim. ${ }^{25}$ The transition to ICD-10-CA in Canada has not substantially changed coding practices but allowed for provincial variations in the average number of diagnoses recorded per hospitalization. ${ }^{26}$ All vital statistics data used the four-digit ICD-10-CA coding throughout the study period to record the primary cause of death. ${ }^{25}$

\section{Case definitions}

To be considered a case of SRD, an individual aged 12 years and over had to receive at least one relevant ICD code in the physician claims database or the main diagnosis field in the hospitalization database in the fiscal year (April 1 to March 31) (see Supplementary 
Material for specific ICD codes).

Considering that some provinces only use the three-digit ICD-9 coding, ${ }^{24,25}$ an indicator for drug intoxication could not be developed, because these codes were not specific to psychoactive drugs. The use of an overall broad definition of SRD circumvents problems that may arise from changes in specific ICD codes or regional variations in recording practices. Case definitions are based on ICD codes used by previous studies which all used a single code as sufficient to classify an individual as having a SRD. ${ }^{27-31}$ These case definitions have been validated previously (specificity over 90\%, sensitivity between $47-70 \%$ ). However, considering that this study does not aim at assessing the overall prevalence of SRD, but rather estimating how many individuals have a recorded diagnosis of SRD, a single code was considered as a valid measure.

The study period spanned 2001-2002 to 2017-2018. For data concerning specific causes of death, the study period ended in 2015-2016 as some provinces had not completed their mortality data compilation beyond that fiscal year.

\section{Analyses}

Unless indicated otherwise, all results were age-standardized to the 2011 Canadian Census. Annual recorded diagnostic rates represented the number of individuals per 1,000 (\%o in the text) who met case definition criteria in that year. Cumulative diagnostic rates 
represented cases in that and previous years (once a case, always a case). Recorded incidence proportions represent the number of individuals (in \%o) who became cases in the previous 12 months. Annual mortality rates (also in \%o), i.e. the number of deaths within a given fiscal year, were calculated among SRD cumulative cases. This outcome was an indicator of longterm burden, which did not always occur within the same year as the diagnosis. An annual mortality rate was also generated for individuals in the general population. Finally, mortality rate ratios $(M R R)$ were calculated between individuals with recorded SRD and individuals without diagnosed SRD for each specific cause of death. ${ }^{18,32}$ When MRR is greater than one, the mortality rate is higher among individuals with recorded SRD compared to the "general population". MRR indicates an association and that individuals with a recorded SRD diagnosis are more likely to die from a given cause of death than individuals without it, probably because a recorded diagnosis is indicative of better detection due to higher medical needs as well as high comorbidity of SRD with other physical diseases and mental disorders. It should not, therefore, be interpreted as attributable risk or that SRD is a causal factor.

The large sample sizes and almost complete coverage of studied populations allowed the use of non-overlapping $99 \%$ confidence intervals to reduce the possibility that clinically 
irrelevant differences between provinces were judged as significant. ${ }^{33}$ Separate analyses according to sex are available upon request.

\section{Ethics}

The project was approved by the institutional review board of the National Public Health Institute of Quebec and endorsed by the Information Access Commission of Québec. Aggregated data access was further authorized within each province by the appropriate institutional review board.

\section{RESULTS}

\section{Annual recorded diagnostic rates}

The overall annual recorded age-standardized rate of recorded SRD increased from 2001-2002 to 2017-2018 in Alberta (8.0\%o [99\% CI=7.9-8.2] to 12.8\%o [12.6-12.9]); Ontario (11.5\%o [11.4-11.6] to 14.4\%o [14.3-14.5]); and Nova Scotia (6.4\%o [6.2-6.7] to 12.7\%o [12.413.1]), but remained stable in Manitoba (5.5\%o [5.3-5.7] to 5.4\%o [5.3-5.6]) and Québec (7.5\% [7.4-7.6] to 7.5\%o [7.4-7.6]). Table 1 provides the annual recorded rates of SRD by sex and province. For all five provinces, males had significantly higher recorded SRD rates than females. 


\section{Cumulative recorded diagnostic rates}

The cumulative recorded rates of any SRD (Figure 1) increased steadily from 20012002 to $2017-2018$ in all five provinces. Ontario had the highest rate across the years (45.2\%o [45.0-45.4] in 2001-2002 to 84.0\%o [83.8-84.2] in 2017-2018). Alberta rose from the thirdhighest recorded rate in 2001-2002 (32.0\% [31.7-32.2]) to the second-highest in 2017-2018 (65.1\%o [64.8-65.4]), overtaking Nova Scotia (44.8\%o [44.1-45.5] in 2001-2002; 61.0\%o [60.2-61.8] in 2017-2018). Québec (26.7\%o [26.6-26.9] in 2001-2002; 57.0\%o [58.8-57.2] in 2017-2018), followed by Manitoba (24.3\%o [23.9-24.7] in 2001-2002; 41.6\%o [41.1-42.2] in 2017-2018).

[insert Figure 1 here]

Concerning overall alcohol-related disorders (Figure 1, panel B1), Alberta had the highest cumulative rate of recorded diagnosis (41.4\%o [41.1-41.6] in 2017-2018; 20.1\%o [19.0-20.4] in 2001-2002), followed by Ontario (39.1\%o [39.0-39.3] in 2017-2018; 20.6\%o [20.4-20.7] in 2001-2002). The cumulative recorded rates of alcohol-related disorders increased from $18.6 \%$ [18.2-18.9] in 2001-2002 to $25.9 \%$ [ $25.5-26.3$ ] in $2017-2018$ in Manitoba, from $18.1 \%$ [17.9-18.2] in 2001-2002 to $35.0 \%$ [34.8-35.1] in 2017-2018 in Québec, and from 31.9\% [31.4-32.5] in 2001-2002 to 37.0\%o [36.4-37.6] in 2017-2018 in Nova Scotia. 
As shown in panel B2, Figure 1, the high rate of recorded alcohol-related disorders in Alberta appeared to be attributable to diagnoses other than alcohol use disorders, for which Ontario had the highest recorded rate (34.4\%o [34.3-34.5] in 2017-2018; 19.0\%o [18.8-19.1] in 2001-2002), followed by Nova Scotia (31.4\%o [30.9-32.0] in 2017-2018; 23.5\%o [23.124.0] in 2001-2002), by Alberta (26.7\%o [26.5-26.9] in 2017-2018; 14.8\%o [14.6-15.0] in 2001-2002), by Manitoba (22.8\%o [22.4-23.1] in 2017-2018; 16.8\%o [16.4-17.1] in 20012002) and by Québec (21.6\% [21.4-21.7] in 2017-2018; 13.7\%o [13.5-13.8] in 2001-2002).

As presented in figure 1 (panel C1), Ontario had the highest cumulative rate of recorded diagnoses of drug-related disorders with a rate of 58.8\% [58.6-59.0] in 2017-2018 (29.6\% [29.5-29.8] in 2001-2002). Alberta had the second-highest cumulative recorded rate in 2017-2018 (36.4\%o [36.2-36.7]; 13.4\%o [13.2-13.6] in 2001-2002), followed closely by Nova Scotia (33.2\%o [32.6-33.8] in 2017-2018; 17.4\%o [16.9-17.8] in 2001-2002), Québec (32.5\%o [32.4-32.7] in 2017-2018; 11.9\%o [11.8-12.0] in 2001-2002), and Manitoba (21.8\%o [21.4-22.1] in 2017-2018; 7.8\% [7.5-8.0] in 2001-2002).

\section{Recorded incidence proportions}

The recorded incidence proportion for overall SRD slightly, but significantly, increased from 2001-2002 to 2017-2018 in Alberta (4.5\%o [4.3-4.6] to 5.0\%o [4.9-5.0]) and Nova Scotia (3.3\%o [3.1-3.5] to 3,8\%o [3.6-3.7]). However, over the same period, a significant 
decrease for overall recorded SRD was observed in Ontario (6.2\%o [6.2-6.3] to 4.7\%o [4.64.7]), in Québec (4.1\%o [4.1-4.2] to 3.2\%o [3.2-3.3]) and Manitoba, (2.7\%o [2.6-2.8] to 2.0\%o [1.9-2.2]). Figure 2 presents the recorded incidence proportions from 2001-2002 to 20172018 for all five provinces for alcohol-related disorders (panel B1), which include alcohol use disorders (panel B2), and for drug-related disorders (panel C1), including drug use disorders (panel C2).

[insert Figure 2 here]

\section{Mortality rates and MRR}

As shown in Figure 3 (panel A), the mortality rate in the general population decreased slightly in each province from 2001-2002 to 2017-2018. There was also a similar decrease within the SRD population for the following four provinces: from $28.4 \%$ [26.9-30.1] to 19.5\% [18.8-20.2] in Alberta, from 28.0\% [25.0-31.4] to 21.9\%o [20.1-23.9] in Manitoba, from $20.7 \%$ [ $20.1-21.3]$ to $17.7 \%$ [ [17.4-18.0] in Ontario, $31.3 \%$ [30.2-32.4] to $22.9 \%$ [22.323.4] in Québec. The exception was in Nova Scotia where the mortality rate in the SRD population increased from $10.3 \%$ [8.7-12.0] to $13.9 \%$ [ $12.6-15.3]$ over the 17 years. In each province, the SRD population presented a significantly higher mortality rate than in the general population. The profile trends for the other SRD categories in Figure 3 (panels B1, B2, C1 and C2) were similar to overall SRD (panel A). Age-adjusted and unadjusted 
mortality rates by cause of death are presented in the Supplementary Material.

$$
\text { [insert Figure } 3 \text { here] }
$$

Interprovincial comparisons of MRR by causes of death in 2015-2016 are presented in Table 2. In Alberta, Ontario, and Québec, individuals with a recorded diagnosis of SRD had a significantly higher MRR for all causes of deaths compared to those without SRD. Findings were similar in Manitoba, except for diseases of the nervous system, where no difference was detected between the two groups. In these four provinces, SRD was the cause of death with the highest mortality gap. Suicide, other trauma and diseases of the digestive system were also among the causes of death with the highest MRR among individuals with recorded SRD. In Nova Scotia, higher MRR were found for diseases of the digestive system and other causes not classified elsewhere while significantly lower MRR were reported for neoplasms, infectious and parasitic diseases, as well as diseases of the nervous system.

\section{DISCUSSION}

Changes in substance use patterns following legislation (e.g. cannabis legalization), changes in treatment modalities, and the emergence of substance-related (e.g. opioid crisis) and non-substance-related (COVID-19 pandemic) occurrences necessitate the need to track health service utilization for SRD. In combination with other data sources such as 
epidemiological surveys, monitoring these trends may therefore inform service provision and risk factors for preventable mortality help health services better match availability and access to service with needs. These could be included in a Canadian Chronic Disease Surveillance System and may have implications for other countries with similar linked AHD.

Given the public health focus, we used a broad definition of SRD rather than specific diagnoses. Broad categories also increased measurement accuracy by reducing the risk of errors and variability arising from AHD, for example, the use of a broad indicator such as "alcohol-related disorder" increased the chances a person would receive the same ICD code if two different physicians were doing the examination. If fine-grained analyses were performed, one physician might code for "alcohol acute intoxication", while another for "alcohol dependence", depending on whether the focus is on immediate care or the underlying condition. Overall annual recorded rates of SRD increased from 2001-2002 to 2017-2018 in Alberta, Ontario, and Nova Scotia, but remained stable in Manitoba and Québec. Like previous studies, emergency department visits related to SRD increased over time in Alberta or to alcohol problems in Ontario. ${ }^{34,35}$ Currently, Canadian epidemiological data on SRD cannot be used to provide consistent temporal trend information as the relevant surveys use different methodologies to assess substance abuse and dependence. ${ }^{36}$ Our results 
thus provide relatively consistent data across time on the recorded diagnosis of SRD in five Canadian provinces.

In all provinces, the annual recorded rates of SRD were lower than self-reported SUD diagnoses in the Canadian 2012 epidemiological survey on addiction and mental disorders. ${ }^{11}$ Epidemiological surveys aim to quantify the prevalence of SRD in the general population, while our data report on the rates of recorded SRD in the public medical system. Not everyone who meets diagnostic criteria for SRD will have immediate contact with medical services, and the interval may vary between provinces. This is particularly relevant for estimates of annual rather than cumulative prevalence. In addition, they may not present to services at all. For instance, according to the 2012 CCHS, only $17.2 \%$ of individuals with a single SUD diagnosis and $62.3 \%$ with comorbid mood/anxiety disorders had used professional mental health and addiction services in the previous year. Cumulative recorded SRD diagnostic rates also have the advantage of capturing long-term consequences such as cirrhosis or mortality. Cumulative recorded rates can, however, overestimate the long-term burden of diagnosed SRD, because individuals whose SRD has resolved will remain counted. On the other hand, up to $54 \%$ of individuals with SRD will be considered as "remitted" after an average follow-up period of 17 years. ${ }^{37}$ Importantly, this overestimation is also inherent 
in the definition of lifetime prevalence, which includes individuals who also no longer fit the case definition.

These descriptive rates are not sufficiently informative to quantify the current disease burden of SRD. However, the data remain useful as they record annual and cumulative SRD diagnoses by physicians, mainly general practitioners. The annual recorded SRD diagnostic rates confirm epidemiological findings that SRD are under-detected and under-treated in primary care. Policies that would support better detection, patient engagement and treatment at the primary care level in collaboration (and support) with specialist addiction services, could result in higher annual recorded SRD diagnoses, and possibly a lower eventual mortality gap.

This study also shows divergent rates and patterns across the five provinces. This observation was also reported in another study of hospitalizations related to alcohol in 2015$2016{ }^{41}$ Many factors can explain these inter-provincial variations: sociodemographic and socioeconomic composition of the population, different access to psychoactive substances, degree of implementation of various substance prevention programs, as well as availability and access to adequate health and psychosocial interventions. ${ }^{38}$ Provision of harm reduction strategies such as needle exchange programs and supervised injection sites also vary. ${ }^{39}$ 
The apparent decrease in mortality over time within the SRD population may be surprising in light of the opioid crisis. However, this obscures the annual increase in raw numbers of deaths within the SRD population and is explained by the greater increase in cumulative recorded rates of SRD when compared to annual deaths. The MRRs reported in this study were consistent with findings from the United States ${ }^{40}$, Denmark ${ }^{18}$ and Norway ${ }^{41}$ where accidents, injuries, overdoses, suicides, or homicides were the main causes of death among individuals with SRD, all of which were preventable. These deaths may have lowered the cancer MRR among individuals with SRD, as fatal trauma, suicide and lethal overdose preceded any cancer diagnosis. Otherwise, the decline in mortality rate in the general population over the years was expected and had been previously explained to higher life expectancies due to better management of neoplasms and cardiovascular diseases in Canada. $^{42}$

\section{Limitations}

This study presents some limitations that need consideration when interpreting the results. First, AHD were originally conceived for administrative purposes, not for answering research questions. ${ }^{43}$ Variables (e.g. socioeconomic status, ethnicity, quality of life, psychosocial characteristics) that may be relevant for research objectives were not always available. Second, coding accuracy even for recorded diagnoses can potentially be impeded 
by clerical errors, limited coding possibilities (e.g. number of diagnoses that be recorded, level of precision of a given code [diagnostic clustering], etc.), diagnostic misclassification by physicians or coders, and omission because it was perceived as irrelevant for administrative purposes. ${ }^{43,44}$ Third, only the primary diagnosis is recorded in the physician's claim database in several provinces. If the main reason for consultation was not SRD, this diagnosis will not be recorded. Fourth, we mainly identified individuals who saw a physician remunerated using a service-for-fee system, but not individuals who only consulted physicians receiving alternative forms of payment or who attended exclusively addiction rehabilitation centres, community organizations or psychosocial services. However, there is a high probability that an individual with a SRD will end up using billable medical services given the diverse health consequences of these conditions. ${ }^{45,46}$ The addition of existing databases on psychosocial services would allow better coverage of the SRD treated population. Future research should look at developing surveillance systems for specific communities (inmates, non-permanent residents, etc.) that are both adapted to their needs and can be incorporated into the larger Canadian surveillance system. Fifth, interprovincial variations in SRD definition, data availability and coding practices limit the scope for comparing claims, hospitalizations and vital statistics. For example, the extremely divergent MRRs in Nova Scotia compared to the four other provinces, suggest different procedures in 
recording mortality data, rather than a real variation in mortality pattern. To allow future interprovincial comparisons, standardized coding procedures should be considered. Nonetheless, because the purpose of public health surveillance is to make broad comparisons and identify high-level problems, information on general and global trends is preferred to fine-grained details.

Finally, rates were only obtained in five out of ten provinces and did not include the territories. However, the five provinces in this analysis represent $79 \%$ of the Canadian population. Linked AHD also have some strengths over other methodologies in that they allow long-term follow-up of cohorts with negligible attrition and give information on comorbidities, medical treatments and outcomes like trauma. Recording bias is minimized because the provision of billing data is required for physician payment.

\section{CONCLUSION}

The ongoing opioid crisis and the legalization of cannabis in Canada, the United States and elsewhere have led to increasing awareness of the need for data to inform health care about detection and treatment of SRD, including alcohol and other drugs. In both the United States and Canada, there is growing interest in establishing a national surveillance

system for mental disorders and SRD. ${ }^{47}$ Surveillance of SRD can be developed in Canada 
and ultimately help to prevent and control the associated burden. This study demonstrates that provincial data sources allow for monitoring SRD because they do capture the detection and treatment patterns of patients and thus have the potential to evaluate the impact of policies on health outcomes, such as mortality gaps. Analyses of temporal trends of services utilization, interventions and health outcomes would allow assessing the impact of preventive measures that will increase greater awareness, detection, and treatment of SRD in jurisdictions where relevant linked AHD are available. 


\section{DATA ACCESS}

The data provided by the different health jurisdictions cannot be publicly shared, because they contain confidential information. Individuals can potentially be re-identified through data triangulation if they present sufficient specific or unique sociodemographic and health characteristics.

\section{ACKNOWLEDGEMENTS}

The authors thank Victoria Massamba, Simon Chen, Abigail Amartey, Kinwah Fung, and Sima Gandhi for their contribution to this study.

The authors acknowledge the Manitoba Centre for Health Policy for use of data contained in the Manitoba Population Research Data Repository (HIPC\#2018/2019-52).

DJA holds a clinical scientist career award from the Fonds de Recherche du Québec (FRQS).

Gareth Hopkin has previously worked at the Institute of Health Economics and has received grants from the Government of Alberta outside of the submitted work.

The authors acknowledge the support of the Quebec Network on Suicide, Mood Disorders and Associated Disorders through their services and public health platform.

\section{CONFLICTS OF INTEREST}

None to declare.

\section{DISCLOSURE}

The results and conclusions are those of the authors and no official endorsement by the Manitoba Centre for Health Policy, Manitoba Health, or Manitoba Vital Statistics is intended or should be inferred. Data used in this study are from the Manitoba Population Research Data Repository housed at the 
Manitoba Centre for Health Policy, University of Manitoba and were derived from data provided by Manitoba Health and Manitoba Vital Statistics.

This study is based in part on data provided by Alberta Health. The interpretation and conclusions contained herein are those of the researchers and do not represent the views of the Government of Alberta. The Government of Alberta does not express any opinion in relation to this study.

\section{FUNDING}

This study has been funded by Health Canada's Substance Use and Addiction Program. 


\section{REFERENCES}

1. Canadian Substance Use Costs and Harms Scientific Working Group. Canadian Substance Use Costs and Harms (2015-2017). Canadian Centre on Substance Use and Addiction; 2020:1-66. Accessed July 23, 2020. https:/www.ccsa.ca/sites/default/files/2020-06/CSUCH-CanadianSubstance-Use-Costs-Harms-Report-2020-en.pdf

2. Kisely S, Lin E, Lesage A, et al. Use of administrative data for the surveillance of mental disorders in 5 provinces. Can J Psychiatry Rev Can Psychiatr. 2009;54(8):571-575. doi: $10.1177 / 070674370905400810$

3. Kisely S, Asbridge M, Connor J, White A, Pais J, Lin E. Using administrative health data for the surveillance of interventions for alcohol-related harm among young people. CMAJ Can Med Assoc J. 2012;184(1):49-53. doi:10.1503/cmaj.110367

4. Lesage A, Rochette L, Émond V, et al. A surveillance system to monitor excess mortality of people with mental illness in Canada. Can J Psychiatry Rev Can Psychiatr. 2015;60(12):571-579. Accessed June 4, 2020. https://www.ncbi.nlm.nih.gov/pmc/articles/PMC4679166/

5. Huỳnh C, Rochette L, Pelletier É, Lesage A. Définir les troubles liés aux substances psychoactives à partir de données administratives. Santé Ment Au Qué. 2018;43(2):39-64. doi:https://doi.org/10.7202/1058609ar

6. American Psychiatric Association, American Psychiatric Association DSM-5 Task Force. Diagnostic and Statistical Manual of Mental Disorders: DSM-5. American Psychiatric Association; 2013. https://dsm.psychiatryonline.org/pb-assets/dsm/update/DSM5Update2016.pdf

7. American Psychiatric Association, American Psychiatric Association Task Force on DSM-IV. Diagnostic and Statistical Manual of Mental Disorders: DSM-IV-TR. American Psychiatric 
Association; 2000.

8. World Health Organization. Manual of the International Statistical Classification of Diseases, Injuries, and Causes of Death: Based on the Recommendations of the Ninth Revision Conference, 1975, and Adopted by the Twenty-Ninth World Health Assembly. 1975 revision. World Health Organization; 1977. https://apps.who.int/iris/handle/10665/40492

9. World Health Organization. International Statistical Classification of Diseases and Related Health Problems. 10th revision. World Health Organization; 1994. https://apps.who.int/iris/handle/10665/38450

10. Government of Canada. Canadian Tobacco, Alcohol and Drugs (CTADS) Survey: 2017 detailed tables. Published October 30, 2018. Accessed June 4, 2020. https://www.canada.ca/en/healthcanada/services/canadian-tobacco-alcohol-drugs-survey/2017-summary/2017-detailed-tables.html

11. Statistics Canada. Table 13-10-0465-01 Mental health indicators. Accessed July 23, 2020. https://doi.org/10.25318/1310046501-eng

12. Bargagli AM, Hickman M, Davoli M, et al. Drug-related mortality and its impact on adult mortality in eight European countries. Eur J Public Health. 2006;16(2):198-202. doi:10.1093/eurpub/cki168

13. Abdul-Rahman A-K, Card TR, Grainge MJ, Fleming KM. All-cause and cause-specific mortality rates of patients treated for alcohol use disorders: A meta-analysis. Subst Abuse. 2018;39(4):509517. doi:10.1080/08897077.2018.1475318

14. Glei DA, Preston SH. Estimating the impact of drug use on US mortality, 1999-2016. PLOS ONE. 2020;15(1):e0226732. doi:10.1371/journal.pone.0226732 
15. Kendler KS, Ohlsson H, Sundquist K, Sundquist J. Drug abuse associated mortality across the lifespan: A population-based longitudinal cohort and co-relative analysis. Soc Psychiatry Psychiatr Epidemiol. 2017;52(7):877-886. doi:10.1007/s00127-017-1398-5

16. Lumme S, Pirkola S, Manderbacka K, Keskimäki I. Excess mortality in patients with severe mental disorders in 1996-2010 in Finland. PLOS ONE. 2016;11(3):e0152223. doi:10.1371/journal.pone.0152223

17. Merrall ELC, Bird SM, Hutchinson SJ. Mortality of those who attended drug services in Scotland 1996-2006: Record-linkage study. Int J Drug Policy. 2012;23(1):24-32.

doi:10.1016/j.drugpo.2011.05.010

18. Plana-Ripoll O, Pedersen CB, Agerbo E, et al. A comprehensive analysis of mortality-related health metrics associated with mental disorders: A nationwide, register-based cohort study. The Lancet. 2019;394(10211):1827-1835. doi:10.1016/S0140-6736(19)32316-5

19. Westman J, Wahlbeck K, Laursen TM, et al. Mortality and life expectancy of people with alcohol use disorder in Denmark, Finland and Sweden. Acta Psychiatr Scand. 2015;131(4):297-306. doi:10.1111/acps.12330

20. Quan H, Smith M, Bartlett-Esquilant G, Johansen H, Tu K, Lix L. Mining administrative health databases to advance medical science: geographical considerations and untapped potential in Canada. Can J Cardiol. 2012;28(2):152-154. doi:10.1016/j.cjca.2012.01.005

21. Canadian Institute for Health Information. Approaches for Calculating Average Clinical Payments per Physician Using Detailed Alternative Payment Data. Canadian Institute for Health Information; 2015:1-41. 
22. Canadian Institute for Health Information. Physicians in Canada, 2018. Canadian Institute for Health Information; 2019:1-58.

23. Statistics Canada. Population Size and Growth in Canada: Key Results from the 2016 Census. Statistics Canada; 2017:14.

24. Lix LM, Walker R, Quan H, et al. Features of physician services databases in Canada. Chronic Dis Inj Can. 2012;32(4):186-193.

25. Doyle CM, Lix LM, Hemmelgarn BR, Paterson JM, Renoux C. Data variability across Canadian administrative health databases: Differences in content, coding, and completeness. Pharmacoepidemiol Drug Saf. 2020;29(S1):68-77. doi:10.1002/pds.4889

26. Walker RL, Hennessy DA, Johansen H, Sambell C, Lix L, Quan H. Implementation of ICD-10 in Canada: how has it impacted coded hospital discharge data? BMC Health Serv Res. 2012;12(1):149. doi:10.1186/1472-6963-12-149

27. Al Kazzi ES, Lau B, Li T, Schneider EB, Makary MA, Hutfless S. Differences in the Prevalence of Obesity, Smoking and Alcohol in the United States Nationwide Inpatient Sample and the Behavioral Risk Factor Surveillance System. PLOS ONE. 2015;10(11):e0140165. doi:10.1371/journal.pone.0140165

28. Quan H, Li B, Saunders LD, et al. Assessing Validity of ICD-9-CM and ICD-10 Administrative Data in Recording Clinical Conditions in a Unique Dually Coded Database. Health Serv Res. 2008;43(4):1424-1441. doi:https://doi.org/10.1111/j.1475-6773.2007.00822.x

29. Rowe C, Vittinghoff E, Santos G-M, Behar E, Turner C, Coffin PO. Performance Measures of Diagnostic Codes for Detecting Opioid Overdose in the Emergency Department. Acad Emerg 
Med. 2017;24(4):475-483. doi:https://doi.org/10.1111/acem.13121

30. Kim HM, Smith EG, Stano CM, et al. Validation of key behaviourally based mental health diagnoses in administrative data: suicide attempt, alcohol abuse, illicit drug abuse and tobacco use. BMC Health Serv Res. 2012;12(1):18. doi:10.1186/1472-6963-12-18

31. Durand M, Wang Y, Venne F, Lelorier J, Tremblay CL, Abrahamowicz M. Diagnostic accuracy of algorithms to identify hepatitis $\mathrm{C}$ status, AIDS status, alcohol consumption and illicit drug use among patients living with HIV in an administrative healthcare database. Pharmacoepidemiol Drug Saf. 2015;24(9):943-950. doi:https://doi.org/10.1002/pds.3808

32. Chesney E, Goodwin GM, Fazel S. Risks of all-cause and suicide mortality in mental disorders: a meta-review. World Psychiatry. 2014;13(2):153-160. doi:https://doi.org/10.1002/wps.20128

33. Cumming G. Inference by eye: Reading the overlap of independent confidence intervals. Stat Med. 2009;28(2):205-220. doi:10.1002/sim.3471

34. Moe J, Camargo CA, Jelinski S, Erdelyi S, Brubacher J, Rowe BH. Epidemiologic trends in substance and opioid misuse-related emergency department visits in Alberta: A cross-sectional time-series analysis. Can J Public Health. 2018;109(2):164-173. doi:10.17269/s41997-018-00536

35. Myran DT, Hsu AT, Smith G, Tanuseputro P. Rates of emergency department visits attributable to alcohol use in Ontario from 2003 to 2016: A retrospective population-level study. CMAJ. 2019;191(29):E804-E810. doi:10.1503/cmaj.181575

36. Baraldi R, Joubert K, Bordeleau M, Plante N, Institut de la statistique du Québec, Bibliothèque numérique canadienne (Firme). Portrait statistique de la santé mentale des Québécois: résultats 
de l'Enquête sur la santé dans les collectivités canadiennes, Santé mentale 2012 : portrait chiffré.; 2015. Accessed June 4, 2020. http://www.deslibris.ca/ID/246457

37. Fleury M-J, Djouini A, Huỳnh C, et al. Remission from substance use disorders: A systematic review and meta-analysis. Drug Alcohol Depend. 2016;168:293-306. doi:10.1016/j.drugalcdep.2016.08.625

38. Veldhuizen S, Urbanoski K, Cairney J. Geographical variation in the prevalence of problematic substance use in Canada. Can J Psychiatry. 2007;52(7):426-433.

doi:10.1177/070674370705200704

39. Stockings E, Hall WD, Lynskey M, et al. Prevention, early intervention, harm reduction, and treatment of substance use in young people. Lancet Psychiatry. 2016;3(3):280-296. doi:10.1016/S2215-0366(16)00002-X

40. Maynard C, Graves MC, West II, Bumgardner K, Krupski A, Roy-Byrne P. Drug use severity, mortality, and cause of death in primary care patients with substance use disorders. SAGE Open. 2016;6(1):2158244015626225. doi:10.1177/2158244015626225

41. Heiberg IH, Jacobsen BK, Nesvåg R, et al. Total and cause-specific standardized mortality ratios in patients with schizophrenia and/or substance use disorder. PLOS ONE. 2018;13(8):e0202028. doi:10.1371/journal.pone.0202028

42. Institut de la statistique du Québec. Le bilan démographique du Québec. Édition 2019. Institut de la statistique du Québec; 2020:1-180. www.stat.gouv.qc.ca/statistiques/population-demographie/ bilan2019.pdf

43. Hashimoto RE, Brodt ED, Skelly AC, Dettori JR. Administrative database studies: Goldmine or 
goose chase? Evid-Based Spine-Care J. 2014;5(2):74-76. doi:10.1055/s-0034-1390027

44. Johnson EK, Nelson CP. Values and pitfalls of the use of administrative databases for outcomes assessment. J Urol. 2013;190(1):17-18. doi:10.1016/j.juro.2013.04.048

45. Huỳnh C, Ngamini Ngui A, Kairouz S, Lesage A, Fleury M-J. Factors associated with high use of general practitioner and psychiatrist services among patients attending an addiction rehabilitation center. BMC Psychiatry. 2016;16(1):258. doi:10.1186/s12888-016-0974-7

46. Huỳnh C, Ferland F, Blanchette-Martin N, Ménard J-M, Fleury M-J. Factors influencing the frequency of emergency department utilization by individuals with substance use disorders. Psychiatr Q. 2016;87(4):713-728. doi:10.1007/s11126-016-9422-6

47. Lyerla R, Stroup DF. Toward a public health surveillance system for behavioral health. Public Health Rep. 2018;133(4):360-365. doi:10.1177/0033354918772547 


\section{Figure captions}

Figure 1. Age-standardized cumulative recorded diagnostic rates of SRD by province, 2001-2002 to 2017-2018

Figure 2. Age-standardized incidence recorded proportions of SRD by province, 2001-2002 to 20172018

Figure 3. Annual mortality rates among cumulative cases 
Table 1. Age-standardized recorded diagnostic rate (per 1,000) of any substance-related disorder by sex and by province

\begin{tabular}{|c|c|c|c|c|c|c|}
\hline & & Alberta & Manitoba & Ontario & Québec & Nova Scotia \\
\hline \multirow[t]{3}{*}{ Females } & $2001-2002$ & $5.9[5.8-6.1]^{\mathrm{a}}$ & $3.9[3.7-4.1]^{\mathrm{b}}$ & $8.4[8.3-8.5]^{\mathrm{c}}$ & $5.0[4.9-5.1]^{\mathrm{d}}$ & $3.4[3.2-3.7]^{\mathrm{b}}$ \\
\hline & 2011-2012 & $7.4[7.2-7.5]^{\mathrm{a}}$ & $4.8[4.5-5.0]^{\mathrm{b}}$ & $9.1[9.0-9.2]^{\mathrm{c}}$ & $5.7[5.6-5.8]^{\mathrm{d}}$ & $5.2[4.9-5.5]^{\mathrm{b}}$ \\
\hline & $2017-2018$ & $10.1[9.9-10.3]^{\mathrm{a}}$ & $4.8[4.6-5.1]^{\mathrm{b}}$ & $10.4[10.3-10.5]^{a}$ & $5.2[5.1-5.3]^{\mathrm{b}}$ & $8.1[7.7-8.5]^{\mathrm{c}}$ \\
\hline \multirow[t]{3}{*}{ Males } & $2001-2002$ & $10.2[10.0-10.4]^{\mathrm{a}}$ & $7.1[6.8-7.4]^{\mathrm{b}}$ & $14.7[14.5-14.8]^{\mathrm{c}}$ & $10.1[10.0-10.3]^{\mathrm{a}}$ & $10.3[9.8-10.8]^{\mathrm{a}}$ \\
\hline & 2011-2012 & $12.1[11.8-12.3]^{\mathrm{a}}$ & $7.0[6.7-7.3]^{\mathrm{b}}$ & $16.3[16.2-16.4]^{\mathrm{c}}$ & $11.3[11.1-11.4]^{\mathrm{d}}$ & $12.8[12.2-13.3]^{\mathrm{a}}$ \\
\hline & $2017-2018$ & $15.4[15.2-15.7]^{\mathrm{a}}$ & $6.1[5.8-6.3]^{\mathrm{b}}$ & $18.5[18.4-18.7]^{\mathrm{c}}$ & $9.8[9.7-9.9]^{\mathrm{d}}$ & $18.6[18.0-19.3]^{\mathrm{c}}$ \\
\hline
\end{tabular}

Note: Significant differences between provinces are indicated by different superscript letters, based on non-overlapping confidence intervals. In other words, when two or more provinces share the same letter, this indicates that there are no significant differences between them. Data for all time points are available in Table S2 (age-standardized rates), and in Tables S3a to S3e (unadjusted rates and raw counts) in the Supplementary Material. 
Table 2. Age-adjusted mortality rate ratios by cause of death among cumulative cases, 2015-2016

\begin{tabular}{|c|c|c|c|c|c|}
\hline & Alberta & Manitoba & Ontario & Québec & Nova Scotia \\
\hline \multicolumn{6}{|l|}{ Neoplasms } \\
\hline (ICD-9: 140-239; ICD-10-CA: C00-C99, D00- & $2.0[1.8-2.2]^{a}$ & $1.9[1.5-2.3]^{\mathrm{a}}$ & $2.0[2.0-2.1]^{\mathrm{a}}$ & $2.5[2.4-2.7]^{b}$ & $0.3[0.2-0.5]^{\mathrm{c}}$ \\
\hline \multicolumn{6}{|l|}{ D49) } \\
\hline \multicolumn{6}{|l|}{ Diseases of the circulatory system } \\
\hline (ICD-9: 390-459; ICD-10-CA: I00-I99) & $2.4[2.2-2.6]^{\mathrm{a}}$ & $1.8[1.5-2.2]^{\mathrm{a}}$ & $2.2[2.2-2.4]^{\mathrm{a}}$ & $2.9[2.7-3.1]^{b}$ & $0.7[0.4-1.1]^{\mathrm{c}}$ \\
\hline \multicolumn{6}{|l|}{ Dementia } \\
\hline (ICD-9: 290, 293, 294, 310; ICD-10-CA: F00- & $3.1[2.6-3.7]^{a}$ & $1.6[1.0-2.4]^{b}$ & $2.9[2.6-3.1]^{\mathrm{a}}$ & $4.7[4.2-5.2]^{\mathrm{c}}$ & $0.7[0.4-1.2]^{\mathrm{b}}$ \\
\hline \multicolumn{6}{|l|}{ F09) } \\
\hline Diseases of the digestive system & & & & & $6.1[3.5-$ \\
\hline (ICD-9: 520-579; ICD-10-CA: K00-K99) & $5.0[4.1-6.2]^{\mathrm{a}, \mathrm{b}}$ & $4.0[2.7-6.2]^{\mathrm{a}, \mathrm{b}}$ & $4.2[3.8-4.6]^{\mathrm{a}}$ & $6.0[5.3-6.8]^{b}$ & $10.7]^{\mathrm{a}, \mathrm{b}}$ \\
\hline Endocrine, nutritional, and metabolic diseases & & & & & \\
\hline (ICD-9: 240-279; ICD-10-CA: E00-E99) & $2.6[2.0-3.5]^{\mathrm{a}, \mathrm{b}}$ & $1.9[1.2-3.1]^{\mathrm{a}, \mathrm{c}}$ & $2.6[2.3-2.9]^{\mathrm{a}}$ & $3.8[3.3-4.4]^{b}$ & $0.6[0.3-1.3]^{\mathrm{c}}$ \\
\hline
\end{tabular}


Infectious and parasitic diseases

(ICD-9: 0-139; ICD-10-CA: A00-A99, B00-B99, $4.3[3.2 \text { - 5.8 }]^{\mathrm{a}}$

$4.1[2.3-7.2]^{\mathrm{a}} \quad 3.8[3.3-4.3]^{\mathrm{a}} \quad 4.6[3.8-5.5]^{\mathrm{a}} \quad 0.2[0.1-0.7]^{\mathrm{b}}$ U04)

Diseases of the nervous system

(ICD-9: 320-389; ICD-10-CA: G00-G99, H00-

$2.9[2.2-3.7]^{\mathrm{a}} \quad 1.0[0.5-2.0]^{\mathrm{b}}$

$2.2[2.0-2.5]^{\mathrm{a}, \mathrm{b}} \quad 3.1[2.8-3.4]^{\mathrm{a}}$

$0.2[0.1-0.5]^{\mathrm{c}}$

H99)

Diseases of the respiratory system

(ICD-9: 460-519; ICD-10-CA: J00-J99)

$3.6[3.1-4.1]^{\mathrm{a}, \mathrm{b}} \quad 2.7[2.0-3.7]^{\mathrm{a}} \quad 3.0[2.8-3.2]^{\mathrm{a}} \quad 4.2[3.9-4.6]^{\mathrm{b}} \quad 0.8[0.5-1.4]^{\mathrm{c}}$

Substance-related disorders

$86.4[59.2-$

$37.4[22.3$ -

$90.1[68.7$ -

169.1 [105.6 -

Data not

(see Table S1)

$126.1]^{\mathrm{a}, \mathrm{b}}$

$62.5]^{\mathrm{a}}$

118.1 $]^{\mathrm{b}}$

$270.8]^{b}$

available

Suicide

(ICD-10-CA: X60-X85)

$9.6[7.7-12.1]^{\mathrm{a}} \quad 8.3[5.1-13.5]^{\mathrm{a}, \mathrm{b}} \quad 6.1[5.2-7.2]^{\mathrm{b}}$

$8.9[7.4-10.6]^{\mathrm{a}} \quad 1.2[0.5-3.0]^{\mathrm{c}}$

Trauma (excluding suicide)

(ICD-9: 800-899; ICD-10-CA: S00-S99, T00-

$9.1[7.9-10.4]^{\mathrm{a}} \quad 7.8[6.0-10.3]^{\mathrm{a}, \mathrm{c}} \quad 5.2[4.8-5.6]^{\mathrm{b}}$

$5.8[5.1-6.6]^{b, c}$

$1.3[0.6-3.0]^{\mathrm{d}}$

T99, W00-W99, X00- -X99) 
Other causes

(all remaining codes not listed above)

Unknown causes $2.5[2.0-3.3]^{\mathrm{a}, \mathrm{b}} \quad 2.3[1.6-3.3]^{\mathrm{a}, \mathrm{b}}$

.

$3.8[2.8-5.1]^{\mathrm{a}}$

Data not

available
2.4 [1.2 -

$5.0]^{a, b}$

$2.2[2.0-2.5]^{\mathrm{b}} \quad 3.1[2.6-3.7]^{\mathrm{a}}$ $0.8[0.4-1.8]^{\mathrm{c}}$

Note: Data in bold indicates that the death rate for this specific cause is significantly lower or higher among SRD cases compared to individuals without a recorded SRD diagnosis. Significant differences between provinces are indicated by different superscript letters, based on non-overlapping confidence intervals. In other words, when two or more provinces share the same letter, this indicates that there are no significant differences between them. Data for raw counts and age-adjusted and unadjusted mortality rates by cause of death and by year for both groups (recorded SRD cases vs cases with no recorded SRD diagnoses) are available in Tables S4a to S4e in the Supplementary Material. 
SUPPLEMENTARY MATERIAL

Table S1. ICD codes to define substance-related disorders cases

\begin{tabular}{|c|c|c|c|}
\hline $\begin{array}{l}\text { Category by } \\
\text { substance }\end{array}$ & $\begin{array}{l}\text { Category by type } \\
\text { of disorder and } \\
\text { by substance }\end{array}$ & ICD-9 & ICD-10-CA \\
\hline \multirow[t]{3}{*}{$\begin{array}{l}\text { Alcohol related } \\
\text { disorders }\end{array}$} & $\begin{array}{l}\text { Alcohol use } \\
\text { disorders }\end{array}$ & 303 & F101 F102 \\
\hline & $\begin{array}{l}\text { Alcohol induced } \\
\text { disorders }\end{array}$ & 291 & $\begin{array}{c}\text { F103 F104 F105 F106 F107 F108 } \\
\text { F109 E244 G312 G621 G721 I426 } \\
\text { K292 K700 K701 K702 K703 K704 } \\
\text { K709 K852 K860 O354 }\end{array}$ \\
\hline & $\begin{array}{c}\text { Alcohol } \\
\text { intoxication }\end{array}$ & 980 & F100 T510 T511 T518 T519 \\
\hline \multirow{2}{*}{$\begin{array}{l}\text { Drug related } \\
\text { disorders } \\
\text { Cannabis, opioids, } \\
\text { cocaine, other } \\
\text { psychostimulants, } \\
\text { hallucinogens, } \\
\text { sedatives and } \\
\text { hypnotics, } \\
\text { inhalants, other } \\
\text { substances or } \\
\text { combined } \\
\text { substances }\end{array}$} & Drug use disorders & 304 & $\begin{array}{c}\text { F111 F112 F121 F122 F131 F132 } \\
\text { F141 F142 F151 F152 F161 F162 } \\
\text { F181 F182 F191 F192 F55 }\end{array}$ \\
\hline & $\begin{array}{l}\text { Drug induced } \\
\text { disorders }\end{array}$ & 292 & $\begin{array}{c}\text { F113 F123 F133 F143 F153 F163 } \\
\text { F183 F193 F114 F124 F134 F144 } \\
\text { F154 F164 F184 F194 F115 F125 } \\
\text { F135 F145 F155 F165 F185 F195 } \\
\text { F116 F126 F136 F146 F156 F166 } \\
\text { F186 F196 F117 F127 F137 F147 } \\
\text { F157 F167 F187 F197 F118 F128 } \\
\text { F138 F148 F158 F168 F188 F198 } \\
\text { F119 F129 F139 F149 F159 F169 } \\
\text { F189 F199 }\end{array}$ \\
\hline
\end{tabular}




\begin{tabular}{|c|c|c|c|c|c|c|c|c|c|c|c|c|c|c|c|}
\hline & \multicolumn{3}{|c|}{ Alberta } & \multicolumn{3}{|c|}{ Manitoba } & \multicolumn{3}{|c|}{ Ontario } & \multicolumn{3}{|c|}{ Québec } & \multicolumn{3}{|c|}{ Nova Scotia } \\
\hline & Females & Males & Total & Females & Males & Total & Females & Males & Total & Females & Males & Total & Females & Males & Total \\
\hline $2001-2002$ & $\begin{array}{c}5.9 \\
{[5.8-6.1]}\end{array}$ & $\begin{array}{c}10.2 \\
{[10.0-10.4]}\end{array}$ & $\begin{array}{c}8.0 \\
{[7.9-8.2]}\end{array}$ & $\begin{array}{c}3.9 \\
{[3.7-4.1]}\end{array}$ & $\begin{array}{c}7.1 \\
{[6.8-7.4]}\end{array}$ & $\begin{array}{c}5.5 \\
{[5.3-5.7]}\end{array}$ & $\begin{array}{c}8.4 \\
{[8.3-8.5]}\end{array}$ & $\begin{array}{c}14.7 \\
{[14.5-14.8]}\end{array}$ & $\begin{array}{c}11.5 \\
{[11.4-11.6]}\end{array}$ & $\begin{array}{c}5.0 \\
{[4.9-5.1]}\end{array}$ & $\begin{array}{c}10.1 \\
{[10.0-10.3]}\end{array}$ & $\begin{array}{c}7.5 \\
{[7.4-7.6]}\end{array}$ & $\begin{array}{c}3.4 \\
{[3.2-3.7]}\end{array}$ & $\begin{array}{c}10.3 \\
{[9.8-10.8]}\end{array}$ & $\begin{array}{c}6.4 \\
{[6.2-6.7]}\end{array}$ \\
\hline $2002-2003$ & $\begin{array}{c}6.1 \\
{[5.9-6.2]}\end{array}$ & $\begin{array}{c}10.3 \\
{[10.1-10.6]}\end{array}$ & $\begin{array}{c}8.2 \\
{[8.0-8.3]}\end{array}$ & $\begin{array}{c}4.0 \\
{[3.8-4.3]}\end{array}$ & $\begin{array}{c}7.4 \\
{[7.0-7.7]}\end{array}$ & $\begin{array}{c}5.7 \\
{[5.5-5.9]}\end{array}$ & $\begin{array}{c}8.4 \\
{[8.3-8.5]}\end{array}$ & $\begin{array}{c}14.5 \\
{[14.3-14.6]}\end{array}$ & $\begin{array}{c}11.4 \\
{[11.3-11.4]}\end{array}$ & $\begin{array}{c}4.9 \\
{[4.8-5.0]}\end{array}$ & $\begin{array}{c}9.7 \\
{[9.6-9.9]}\end{array}$ & $\begin{array}{c}7.2 \\
{[7.1-7.3]}\end{array}$ & $\begin{array}{c}3.4 \\
{[3.2-3.7]}\end{array}$ & $\begin{array}{c}9.7 \\
{[9.2-10.2]}\end{array}$ & $\begin{array}{c}6.2 \\
{[5.9-6.4]}\end{array}$ \\
\hline 2003-2004 & $\begin{array}{c}5.8 \\
{[5.6-6.0]}\end{array}$ & $\begin{array}{c}9.7 \\
{[9.5-10.0]}\end{array}$ & $\begin{array}{c}7.8 \\
{[7.6-7.9]}\end{array}$ & $\begin{array}{c}4.1 \\
{[3.8-4.3]}\end{array}$ & $\begin{array}{c}7.4 \\
{[7.1-7.7]}\end{array}$ & $\begin{array}{c}5.7 \\
{[5.5-5.9]}\end{array}$ & $\begin{array}{c}7.6 \\
{[7.5-7.7]}\end{array}$ & $\begin{array}{c}13.7 \\
{[13.6-13.8]}\end{array}$ & $\begin{array}{c}10.6 \\
{[10.5-10.7]}\end{array}$ & $\begin{array}{c}5.0 \\
{[4.9-5.1]}\end{array}$ & $\begin{array}{c}9.9 \\
{[9.8-10.1]}\end{array}$ & $\begin{array}{c}7.4 \\
{[7.3-7.4]}\end{array}$ & $\begin{array}{c}3.2 \\
{[3.0-3.4]}\end{array}$ & $\begin{array}{c}9.0 \\
{[8.6-9.5]}\end{array}$ & $\begin{array}{c}5.8 \\
{[5.5-6.0]}\end{array}$ \\
\hline $2004-2005$ & $\begin{array}{c}6.1 \\
{[5.9-6.3]}\end{array}$ & $\begin{array}{c}10.4 \\
{[10.2-10.6]}\end{array}$ & $\begin{array}{c}8.2 \\
{[8.1-8.4]}\end{array}$ & $\begin{array}{c}4.3 \\
{[4.1-4.6]}\end{array}$ & $\begin{array}{c}7.5 \\
{[7.2-7.8]}\end{array}$ & $\begin{array}{c}5.9 \\
{[5.7-6.1]}\end{array}$ & $\begin{array}{c}7.4 \\
{[7.3-7.5]}\end{array}$ & $\begin{array}{c}13.7 \\
{[13.5-13.8]}\end{array}$ & $\begin{array}{c}10.5 \\
{[10.4-10.6]}\end{array}$ & $\begin{array}{c}4.9 \\
{[4.8-5.0]}\end{array}$ & $\begin{array}{c}10.1 \\
{[9.9-10.2]}\end{array}$ & $\begin{array}{c}7.4 \\
{[7.3-7.5]}\end{array}$ & $\begin{array}{c}3.4 \\
{[3.2-3.7]}\end{array}$ & $\begin{array}{c}9.3 \\
{[8.8-9.7]}\end{array}$ & $\begin{array}{c}6.0 \\
{[5.8-6.3]}\end{array}$ \\
\hline $2005-2006$ & $\begin{array}{c}6.4 \\
{[6.2-6.6]}\end{array}$ & $\begin{array}{c}10.7 \\
{[10.5-10.9]}\end{array}$ & $\begin{array}{c}8.5 \\
{[8.4-8.7]}\end{array}$ & $\begin{array}{c}4.5 \\
{[4.3-4.8]}\end{array}$ & $\begin{array}{c}8.2 \\
{[7.9-8.6]}\end{array}$ & $\begin{array}{c}6.3 \\
{[6.1-6.6]}\end{array}$ & $\begin{array}{c}7.7 \\
{[7.6-7.8]}\end{array}$ & $\begin{array}{c}14.2 \\
{[14.0-14.3]}\end{array}$ & $\begin{array}{c}10.9 \\
{[10.8-10.9]}\end{array}$ & $\begin{array}{c}5.2 \\
{[5.1-5.3]}\end{array}$ & $\begin{array}{c}10.5 \\
{[10.4-10.7]}\end{array}$ & $\begin{array}{c}7.8 \\
{[7.7-7.8]}\end{array}$ & $\begin{array}{c}3.6 \\
{[3.3-3.8]}\end{array}$ & $\begin{array}{c}9.7 \\
{[9.2-10.1]}\end{array}$ & $\begin{array}{c}6.3 \\
{[6.0-6.5]}\end{array}$ \\
\hline $2006-2007$ & $\begin{array}{c}7.0 \\
{[6.8-7.2]}\end{array}$ & $\begin{array}{c}11.0 \\
{[10.8-11.2]}\end{array}$ & $\begin{array}{c}9.0 \\
{[8.8-9.1]}\end{array}$ & $\begin{array}{c}4.6 \\
{[4.3-4.8]}\end{array}$ & $\begin{array}{c}7.9 \\
{[7.6-8.3]}\end{array}$ & $\begin{array}{c}6.2 \\
{[6.0-6.4]}\end{array}$ & $\begin{array}{c}8.0 \\
{[7.9-8.1]}\end{array}$ & $\begin{array}{c}14.3 \\
{[14.2-14.5]}\end{array}$ & $\begin{array}{c}11.1 \\
{[11.0-11.2]}\end{array}$ & $\begin{array}{c}5.4 \\
{[5.3-5.5]}\end{array}$ & $\begin{array}{c}11.0 \\
{[10.8-11.1]}\end{array}$ & $\begin{array}{c}8.1 \\
{[8.0-8.2]}\end{array}$ & $\begin{array}{c}4.0 \\
{[3.8-4.3]}\end{array}$ & $\begin{array}{c}10.2 \\
{[9.7-10.6]}\end{array}$ & $\begin{array}{c}6.7 \\
{[6.5-7.0]}\end{array}$ \\
\hline $2007-2008$ & $\begin{array}{c}7.6 \\
{[7.5-7.8]}\end{array}$ & $\begin{array}{c}11.4 \\
{[11.2-11.7]}\end{array}$ & $\begin{array}{c}9.5 \\
{[9.4-9.7]}\end{array}$ & $\begin{array}{c}4.0 \\
{[3.8-4.2]}\end{array}$ & $\begin{array}{c}6.5 \\
{[6.2-6.8]}\end{array}$ & $\begin{array}{c}5.2 \\
{[5.0-5.4]}\end{array}$ & $\begin{array}{c}8.5 \\
{[8.4-8.6]}\end{array}$ & $\begin{array}{c}14.8 \\
{[14.7-15.0]}\end{array}$ & $\begin{array}{c}11.6 \\
{[11.5-11.7]}\end{array}$ & $\begin{array}{c}5.6 \\
{[5.5-5.7]}\end{array}$ & $\begin{array}{c}11.2 \\
{[11.0-11.3]}\end{array}$ & $\begin{array}{c}8.3 \\
{[8.2-8.4]}\end{array}$ & $\begin{array}{c}4.4 \\
{[4.1-4.7]}\end{array}$ & $\begin{array}{c}11.0 \\
{[10.5-11.5]}\end{array}$ & $\begin{array}{c}7.3 \\
{[7.0-7.6]}\end{array}$ \\
\hline $2008-2009$ & $\begin{array}{c}7.1 \\
{[6.9-7.3]}\end{array}$ & $\begin{array}{c}11.6 \\
{[11.4-11.9]}\end{array}$ & $\begin{array}{c}9.4 \\
{[9.2-9.5]}\end{array}$ & $\begin{array}{c}4.3 \\
{[4.1-4.6]}\end{array}$ & $\begin{array}{c}6.8 \\
{[6.5-7.1]}\end{array}$ & $\begin{array}{c}5.5 \\
{[5.3-5.7]}\end{array}$ & $\begin{array}{c}9.0 \\
{[8.9-9.1]}\end{array}$ & $\begin{array}{c}15.6 \\
{[15.5-15.8]}\end{array}$ & $\begin{array}{c}12.2 \\
{[12.2-12.3]}\end{array}$ & $\begin{array}{c}5.7 \\
{[5.6-5.8]}\end{array}$ & $\begin{array}{c}11.3 \\
{[11.1-11.4]}\end{array}$ & $\begin{array}{c}8.4 \\
{[8.3-8.5]}\end{array}$ & $\begin{array}{c}4.3 \\
{[4.1-4.6]}\end{array}$ & $\begin{array}{c}11.3 \\
{[10.8-11.8]}\end{array}$ & $\begin{array}{c}7.4 \\
{[7.2-7.7]}\end{array}$ \\
\hline $2009-2010$ & $\begin{array}{c}7.1 \\
{[6.9-7.3]}\end{array}$ & $\begin{array}{c}11.8 \\
{[11.6-12.0]}\end{array}$ & $\begin{array}{c}9.4 \\
{[9.3-9.6]}\end{array}$ & $\begin{array}{c}4.2 \\
{[4.0-4.5]}\end{array}$ & $\begin{array}{c}6.7 \\
{[6.4-7.0]}\end{array}$ & $\begin{array}{c}5.4 \\
{[5.3-5.6]}\end{array}$ & $\begin{array}{c}8.8 \\
{[8.7-8.9]}\end{array}$ & $\begin{array}{c}15.5 \\
{[15.4-15.6]}\end{array}$ & $\begin{array}{c}12.1 \\
{[12.0-12.2]}\end{array}$ & $\begin{array}{c}5.7 \\
{[5.6-5.8]}\end{array}$ & $\begin{array}{c}11.3 \\
{[11.2-11.5]}\end{array}$ & $\begin{array}{c}8.4 \\
{[8.3-8.5]}\end{array}$ & $\begin{array}{c}4.5 \\
{[4.3-4.8]}\end{array}$ & $\begin{array}{c}11.7 \\
{[11.2-12.2]}\end{array}$ & $\begin{array}{c}7.7 \\
{[7.5-8.0]}\end{array}$ \\
\hline $2010-2011$ & $\begin{array}{c}7.2 \\
{[7.0-7.3]}\end{array}$ & $\begin{array}{c}11.8 \\
{[11.6-12.0]}\end{array}$ & $\begin{array}{c}9.5 \\
{[9.3-9.6]}\end{array}$ & $\begin{array}{c}4.4 \\
{[4.2-4.6]}\end{array}$ & $\begin{array}{c}6.7 \\
{[6.4-7.0]}\end{array}$ & $\begin{array}{c}5.5 \\
{[5.4-5.7]}\end{array}$ & $\begin{array}{c}8.9 \\
{[8.8-9.0]}\end{array}$ & $\begin{array}{c}15.9 \\
{[15.7-16.0]}\end{array}$ & $\begin{array}{c}12.3 \\
{[12.2-12.4]}\end{array}$ & $\begin{array}{c}5.6 \\
{[5.5-5.7]}\end{array}$ & $\begin{array}{c}11.1 \\
{[11.0-11.3]}\end{array}$ & $\begin{array}{c}8.3 \\
{[8.2-8.4]}\end{array}$ & $\begin{array}{c}4.9 \\
{[4.6-5.2]}\end{array}$ & $\begin{array}{c}12.4 \\
{[11.9-12.9]}\end{array}$ & $\begin{array}{c}8.2 \\
{[7.9-8.5]}\end{array}$ \\
\hline $2011-2012$ & $\begin{array}{c}7.4 \\
{[7.2-7.5]}\end{array}$ & $\begin{array}{c}12.1 \\
{[11.8-12.3]}\end{array}$ & $\begin{array}{c}9.7 \\
{[9.6-9.8]}\end{array}$ & $\begin{array}{c}4.8 \\
{[4.5-5.0]}\end{array}$ & $\begin{array}{c}7.0 \\
{[6.7-7.3]}\end{array}$ & $\begin{array}{c}5.8 \\
{[5.7-6.0]}\end{array}$ & $\begin{array}{c}9.1 \\
{[9.0-9.2]}\end{array}$ & $\begin{array}{c}16.3 \\
{[16.2-16.4]}\end{array}$ & $\begin{array}{c}12.7 \\
{[12.6-12.7]}\end{array}$ & $\begin{array}{c}5.7 \\
{[5.6-5.8]}\end{array}$ & $\begin{array}{c}11.3 \\
{[11.1-11.4]}\end{array}$ & $\begin{array}{c}8.4 \\
{[8.3-8.5]}\end{array}$ & $\begin{array}{c}5.2 \\
{[4.9-5.5]}\end{array}$ & $\begin{array}{c}12.8 \\
{[12.2-13.3]}\end{array}$ & $\begin{array}{c}8.6 \\
{[8.3-8.9]}\end{array}$ \\
\hline $2012-2013$ & $\begin{array}{c}7.5 \\
{[7.3-7.6]}\end{array}$ & $\begin{array}{c}12.1 \\
{[11.9-12.3]}\end{array}$ & $\begin{array}{c}9.8 \\
{[9.7-9.9]}\end{array}$ & $\begin{array}{c}4.8 \\
{[4.6-5.1]}\end{array}$ & $\begin{array}{c}6.9 \\
{[6.6-7.2]}\end{array}$ & $\begin{array}{c}5.8 \\
{[5.7-6.0]}\end{array}$ & $\begin{array}{c}9.1 \\
{[9.0-9.2]}\end{array}$ & $\begin{array}{c}16.0 \\
{[15.9-16.2]}\end{array}$ & $\begin{array}{c}12.5 \\
{[12.4-12.6]}\end{array}$ & $\begin{array}{c}5.8 \\
{[5.7-6.0]}\end{array}$ & $\begin{array}{c}11.3 \\
{[11.2-11.5]}\end{array}$ & $\begin{array}{c}8.5 \\
{[8.4-8.6]}\end{array}$ & $\begin{array}{c}5.6 \\
{[5.3-5.9]}\end{array}$ & $\begin{array}{c}13.1 \\
{[12.5-13.6]}\end{array}$ & $\begin{array}{c}8.9 \\
{[8.6-9.2]}\end{array}$ \\
\hline $2013-2014$ & $\begin{array}{c}8.0 \\
{[7.8-8.2]}\end{array}$ & $\begin{array}{c}12.7 \\
{[12.5-12.9]}\end{array}$ & $\begin{array}{c}10.4 \\
{[10.2-10.5]}\end{array}$ & $\begin{array}{c}4.8 \\
{[4.6-5.0]}\end{array}$ & $\begin{array}{c}6.6 \\
{[6.3-6.8]}\end{array}$ & $\begin{array}{c}5.7 \\
{[5.5-5.8]}\end{array}$ & $\begin{array}{c}9.3 \\
{[9.2-9.4]}\end{array}$ & $\begin{array}{c}16.5 \\
{[16.4-16.7]}\end{array}$ & $\begin{array}{c}12.9 \\
{[12.8-13.0]}\end{array}$ & $\begin{array}{c}5.8 \\
{[5.7-5.9]}\end{array}$ & $\begin{array}{c}11.1 \\
{[11.0-11.2]}\end{array}$ & $\begin{array}{c}8.4 \\
{[8.3-8.5]}\end{array}$ & $\begin{array}{c}6.0 \\
{[5.6-6.3]}\end{array}$ & $\begin{array}{c}14.2 \\
{[13.6-14.8]}\end{array}$ & $\begin{array}{c}9.6 \\
{[9.3-9.9]}\end{array}$ \\
\hline $2014-2015$ & $\begin{array}{c}8.1 \\
{[8.0-8.3]}\end{array}$ & $\begin{array}{c}13.1 \\
{[12.8-13.3]}\end{array}$ & $\begin{array}{c}10.6 \\
{[10.5-10.8]}\end{array}$ & $\begin{array}{c}4.7 \\
{[4.5-4.9]}\end{array}$ & $\begin{array}{c}6.2 \\
{[6.0-6.5]}\end{array}$ & $\begin{array}{c}5.5 \\
{[5.3-5.6]}\end{array}$ & $\begin{array}{c}9.5 \\
{[9.4-9.6]}\end{array}$ & $\begin{array}{c}16.9 \\
{[16.7-17.0]}\end{array}$ & $\begin{array}{c}13.1 \\
{[13.0-13.2]}\end{array}$ & $\begin{array}{c}5.8 \\
{[5.7-5.9]}\end{array}$ & $\begin{array}{c}11.0 \\
{[10.9-11.1]}\end{array}$ & $\begin{array}{c}8.4 \\
{[8.3-8.4]}\end{array}$ & $\begin{array}{c}5.8 \\
{[5.5-6.2]}\end{array}$ & $\begin{array}{c}14.0 \\
{[13.4-14.6]}\end{array}$ & $\begin{array}{c}9.4 \\
{[9.1-9.7]}\end{array}$ \\
\hline $2015-2016$ & $\begin{array}{c}8.8 \\
{[8.6-8.9]}\end{array}$ & $\begin{array}{c}14.1 \\
{[13.9-14.3]}\end{array}$ & $\begin{array}{c}11.5 \\
{[11.3-11.6]}\end{array}$ & $\begin{array}{c}4.6 \\
{[4.3-4.8]}\end{array}$ & $\begin{array}{c}6.0 \\
{[5.7-6.2]}\end{array}$ & $\begin{array}{c}5.3 \\
{[5.1-5.4]}\end{array}$ & $\begin{array}{c}9.8 \\
{[9.7-9.9]}\end{array}$ & $\begin{array}{c}17.4 \\
{[17.3-17.6]}\end{array}$ & $\begin{array}{c}13.5 \\
{[13.5-13.6]}\end{array}$ & $\begin{array}{c}5.7 \\
{[5.6-5.8]}\end{array}$ & $\begin{array}{c}10.9 \\
{[10.7-11.0]}\end{array}$ & $\begin{array}{c}8.2 \\
{[8.2-8.3]}\end{array}$ & $\begin{array}{c}6.5 \\
{[6.2-6.9]}\end{array}$ & $\begin{array}{c}14.9 \\
{[14.4-15.5]}\end{array}$ & $\begin{array}{c}10.2 \\
{[9.9-10.6]}\end{array}$ \\
\hline 2016-2017 & $\begin{array}{c}9.5 \\
{[9.3-9.7]}\end{array}$ & $\begin{array}{c}14.9 \\
{[14.7-15.1]}\end{array}$ & $\begin{array}{c}12.2 \\
{[12.1-12.4]}\end{array}$ & $\begin{array}{c}4.7 \\
{[4.5-4.9]}\end{array}$ & $\begin{array}{c}6.2 \\
{[5.9-6.4]}\end{array}$ & $\begin{array}{c}5.4 \\
{[5.2-5.6]}\end{array}$ & $\begin{array}{c}10.1 \\
{[10.0-10.2]}\end{array}$ & $\begin{array}{c}17.9 \\
{[17.8-18.1]}\end{array}$ & $\begin{array}{c}13.9 \\
{[13.9-14.0]}\end{array}$ & $\begin{array}{c}5.8 \\
{[5.7-5.9]}\end{array}$ & $\begin{array}{c}10.7 \\
{[10.5-10.8]}\end{array}$ & $\begin{array}{c}8.2 \\
{[8.1-8.3]}\end{array}$ & $\begin{array}{c}8.0 \\
{[7.6-8.4]}\end{array}$ & $\begin{array}{c}17.9 \\
{[17.3-18.6]}\end{array}$ & $\begin{array}{c}12.4 \\
{[12.0-12.7]}\end{array}$ \\
\hline $2017-2018$ & $\begin{array}{c}10.1 \\
{[9.9-10.3]}\end{array}$ & $\begin{array}{c}15.4 \\
{[15.2-15.7]}\end{array}$ & $\begin{array}{c}12.8 \\
{[12.6-12.9]}\end{array}$ & $\begin{array}{c}4.8 \\
{[4.6-5.1]}\end{array}$ & $\begin{array}{c}6.1 \\
{[5.8-6.3]}\end{array}$ & $\begin{array}{c}5.4 \\
{[5.3-5.6]}\end{array}$ & $\begin{array}{c}10.4 \\
{[10.3-10.5]}\end{array}$ & $\begin{array}{c}18.5 \\
{[18.4-18.7]}\end{array}$ & $\begin{array}{c}14.4 \\
{[14.3-14.5]}\end{array}$ & $\begin{array}{c}5.2 \\
{[5.1-5.3]}\end{array}$ & $\begin{array}{c}9.8 \\
{[9.7-9.9]}\end{array}$ & $\begin{array}{c}7.5 \\
{[7.4-7.6]}\end{array}$ & $\begin{array}{c}8.1 \\
{[7.7-8.5]}\end{array}$ & $\begin{array}{c}18.6 \\
{[18.0-19.3]}\end{array}$ & $\begin{array}{c}12.7 \\
{[12.4-13.1]}\end{array}$ \\
\hline
\end{tabular}



Table S3a. Unadjusted annual recorded SRD diagnostic rates and raw counts, Alberta, 2001-2002 to 2017-2018

\begin{tabular}{|c|c|c|c|c|c|c|}
\hline & \multicolumn{2}{|c|}{ Females } & \multicolumn{2}{|c|}{ Males } & \multicolumn{2}{|c|}{ Total } \\
\hline & $\mathrm{N}$ & $\begin{array}{l}\text { Unadjusted } \\
\text { rate }\end{array}$ & $\mathrm{N}$ & $\begin{array}{l}\text { Unadjusted } \\
\text { rate }\end{array}$ & $\mathrm{N}$ & $\begin{array}{l}\text { Unadjusted } \\
\text { rate }\end{array}$ \\
\hline 2001-2002 & 8080 & $\begin{array}{c}6.1 \\
{[6.0-6.3]}\end{array}$ & 13470 & $\begin{array}{c}10.3 \\
{[10.0-10.5]}\end{array}$ & 21550 & $\begin{array}{c}8.2 \\
{[8.1-8.3]}\end{array}$ \\
\hline $2002-2003$ & 8420 & $\begin{array}{c}6.2 \\
{[6.1-6.4]}\end{array}$ & 14075 & $\begin{array}{c}10.5 \\
{[10.3-10.7]}\end{array}$ & 22490 & $\begin{array}{c}8.4 \\
{[8.2-8.5]}\end{array}$ \\
\hline 2003-2004 & 8180 & $\begin{array}{c}6.0 \\
{[5.8-6.1]}\end{array}$ & 13555 & $\begin{array}{c}9.9 \\
{[9.7-10.2]}\end{array}$ & 21735 & $\begin{array}{c}7.9 \\
{[7.8-8.1]}\end{array}$ \\
\hline 2004-2005 & 8790 & $\begin{array}{c}6.3 \\
{[6.1-6.5]}\end{array}$ & 14720 & $\begin{array}{c}10.6 \\
{[10.4-10.9]}\end{array}$ & 23510 & $\begin{array}{c}8.5 \\
{[8.3-8.6]}\end{array}$ \\
\hline $2005-2006$ & 9430 & $\begin{array}{c}6.6 \\
{[6.4-6.8]}\end{array}$ & 15370 & $\begin{array}{c}10.9 \\
{[10.7-11.1]}\end{array}$ & 24800 & $\begin{array}{c}8.7 \\
{[8.6-8.9]}\end{array}$ \\
\hline $2006-2007$ & 10665 & $\begin{array}{c}7.2 \\
{[7.1-7.4]}\end{array}$ & 16390 & $\begin{array}{c}11.2 \\
{[11.0-11.5]}\end{array}$ & 27055 & $\begin{array}{c}9.2 \\
{[9.1-9.4]}\end{array}$ \\
\hline $2007-2008$ & 11860 & $\begin{array}{c}7.8 \\
{[7.7-8.0]}\end{array}$ & 17565 & $\begin{array}{c}11.7 \\
{[11.4-11.9]}\end{array}$ & 29425 & $\begin{array}{c}9.8 \\
{[9.6-9.9]}\end{array}$ \\
\hline 2008-2009 & 11345 & $\begin{array}{c}7.3 \\
{[7.1-7.5]}\end{array}$ & 18350 & $\begin{array}{c}11.9 \\
{[11.6-12.1]}\end{array}$ & 29695 & $\begin{array}{c}9.6 \\
{[9.4-9.7]}\end{array}$ \\
\hline 2009-2010 & 11610 & $\begin{array}{c}7.3 \\
{[7.1-7.5]}\end{array}$ & 19045 & $\begin{array}{c}12.0 \\
{[11.8-12.2]}\end{array}$ & 30650 & $\begin{array}{c}9.7 \\
{[9.5-9.8]}\end{array}$ \\
\hline 2010-2011 & 11950 & $\begin{array}{c}7.3 \\
{[7.2-7.5]}\end{array}$ & 19570 & $\begin{array}{c}12.0 \\
{[11.8-12.2]}\end{array}$ & 31515 & $\begin{array}{c}9.7 \\
{[9.5-9.8]}\end{array}$ \\
\hline 2011-2012 & 12570 & $\begin{array}{c}7.5 \\
{[7.3-7.7]}\end{array}$ & 20640 & $\begin{array}{c}12.3 \\
{[12.1-12.5]}\end{array}$ & 33210 & $\begin{array}{c}9.9 \\
{[9.8-10.0]}\end{array}$ \\
\hline $2012-2013$ & 13220 & $\begin{array}{c}7.6 \\
{[7.5-7.8]}\end{array}$ & 21620 & $\begin{array}{c}12.3 \\
{[12.1-12.6]}\end{array}$ & 34840 & $\begin{array}{c}10.0 \\
{[9.9-10.1]}\end{array}$ \\
\hline 2013-2014 & 14610 & $\begin{array}{c}8.1 \\
{[8.0-8.3]}\end{array}$ & 23740 & $\begin{array}{c}13.0 \\
{[12.8-13.2]}\end{array}$ & 38345 & $\begin{array}{c}10.6 \\
{[10.5-10.7]}\end{array}$ \\
\hline 2014-2015 & 15310 & $\begin{array}{c}8.3 \\
{[8.1-8.4]}\end{array}$ & 25260 & $\begin{array}{c}13.4 \\
{[13.1-13.6]}\end{array}$ & 40575 & $\begin{array}{c}10.8 \\
{[10.7-11.0]}\end{array}$ \\
\hline $2015-2016$ & 16940 & $\begin{array}{c}8.9 \\
{[8.8-9.1]}\end{array}$ & 28025 & $\begin{array}{c}14.5 \\
{[14.3-14.7]}\end{array}$ & 44970 & $\begin{array}{c}11.7 \\
{[11.6-11.9]}\end{array}$ \\
\hline 2016-2017 & 18605 & $\begin{array}{c}9.7 \\
{[9.5-9.8]}\end{array}$ & 29910 & $\begin{array}{c}15.3 \\
{[15.0-15.5]}\end{array}$ & 48515 & $\begin{array}{c}12.5 \\
{[12.3-12.6]}\end{array}$ \\
\hline 2017-2018 & 20080 & $\begin{array}{c}10.3 \\
{[10.1-10.4]}\end{array}$ & 31495 & $\begin{array}{c}15.8 \\
{[15.6-16.1]}\end{array}$ & 51575 & $\begin{array}{c}13.1 \\
{[12.9-13.2]}\end{array}$ \\
\hline
\end{tabular}


Table S3b. Unadjusted annual recorded SRD diagnostic rates and raw counts, Manitoba, 2001-2002 to 2017-2018

\begin{tabular}{|c|c|c|c|c|c|c|}
\hline & \multicolumn{2}{|c|}{ Females } & \multicolumn{2}{|c|}{ Males } & \multicolumn{2}{|c|}{ Total } \\
\hline & $\mathrm{N}$ & $\begin{array}{c}\text { Unadjusted } \\
\text { rate }\end{array}$ & $\mathrm{N}$ & $\begin{array}{c}\text { Unadjusted } \\
\text { rate }\end{array}$ & $\mathrm{N}$ & $\begin{array}{c}\text { Unadjusted } \\
\text { rate }\end{array}$ \\
\hline 2001-2002 & 1960 & $\begin{array}{c}3.9 \\
{[3.7-4.1]}\end{array}$ & 3445 & $\begin{array}{c}7.1 \\
{[6.8-7.4]}\end{array}$ & 5405 & $\begin{array}{c}5.5 \\
{[5.3-5.7]}\end{array}$ \\
\hline $2002-2003$ & 2075 & $\begin{array}{c}4.1 \\
{[3.9-4.3]}\end{array}$ & 3590 & $\begin{array}{c}7.3 \\
{[7.0-7.7]}\end{array}$ & 5665 & $\begin{array}{c}5.7 \\
{[5.5-5.9]}\end{array}$ \\
\hline $2003-2004$ & 2085 & $\begin{array}{c}4.1 \\
{[3.9-4.3]}\end{array}$ & 3655 & $\begin{array}{c}7.4 \\
{[7.1-7.7]}\end{array}$ & 5740 & $\begin{array}{c}5.7 \\
{[5.5-5.9]}\end{array}$ \\
\hline 2004-2005 & 2245 & $\begin{array}{c}4.4 \\
{[4.1-4.6]}\end{array}$ & 3765 & $\begin{array}{c}7.6 \\
{[7.2-7.9]}\end{array}$ & 6015 & $\begin{array}{c}5.9 \\
{[5.7-6.1]}\end{array}$ \\
\hline $2005-2006$ & 2350 & $\begin{array}{c}4.5 \\
{[4.3-4.8]}\end{array}$ & 4170 & $\begin{array}{c}8.3 \\
{[8.0-8.6]}\end{array}$ & 6520 & $\begin{array}{c}6.4 \\
{[6.2-6.6]}\end{array}$ \\
\hline 2006-2007 & 2380 & $\begin{array}{c}4.6 \\
{[4.3-4.8]}\end{array}$ & 4010 & $\begin{array}{c}7.9 \\
{[7.6-8.3]}\end{array}$ & 6390 & $\begin{array}{c}6.2 \\
{[6.0-6.4]}\end{array}$ \\
\hline $2007-2008$ & 2110 & $\begin{array}{c}4.0 \\
{[3.8-4.2]}\end{array}$ & 3285 & $\begin{array}{c}6.4 \\
{[6.2-6.7]}\end{array}$ & 5400 & $\begin{array}{c}5.2 \\
{[5.0-5.4]}\end{array}$ \\
\hline 2008-2009 & 2300 & $\begin{array}{c}4.3 \\
{[4.1-4.5]}\end{array}$ & 3475 & $\begin{array}{c}6.7 \\
{[6.4-7.0]}\end{array}$ & 5780 & $\begin{array}{c}5.5 \\
{[5.3-5.7]}\end{array}$ \\
\hline $2009-2010$ & 2265 & $\begin{array}{c}4.2 \\
{[4.0-4.4]}\end{array}$ & 3500 & $\begin{array}{c}6.7 \\
{[6.4-7.0]}\end{array}$ & 5765 & $\begin{array}{c}5.4 \\
{[5.3-5.6]}\end{array}$ \\
\hline $2010-2011$ & 2385 & $\begin{array}{c}4.4 \\
{[4.1-4.6]}\end{array}$ & 3570 & $\begin{array}{c}6.7 \\
{[6.4-7.0]}\end{array}$ & 5955 & $\begin{array}{c}5.5 \\
{[5.3-5.7]}\end{array}$ \\
\hline 2011-2012 & 2620 & $\begin{array}{c}4.7 \\
{[4.5-5.0]}\end{array}$ & 3760 & $\begin{array}{c}7.0 \\
{[6.7-7.3]}\end{array}$ & 6385 & $\begin{array}{c}5.8 \\
{[5.7-6.0]}\end{array}$ \\
\hline $2012-2013$ & 2710 & $\begin{array}{c}4.8 \\
{[4.6-5.1]}\end{array}$ & 3790 & $\begin{array}{c}6.9 \\
{[6.6-7.2]}\end{array}$ & 6495 & $\begin{array}{c}5.8 \\
{[5.6-6.0]}\end{array}$ \\
\hline $2013-2014$ & 2705 & $\begin{array}{c}4.7 \\
{[4.5-5.0]}\end{array}$ & 3660 & $\begin{array}{c}6.5 \\
{[6.3-6.8]}\end{array}$ & 6375 & $\begin{array}{c}5.6 \\
{[5.5-5.8]}\end{array}$ \\
\hline 2014-2015 & 2695 & $\begin{array}{c}4.7 \\
{[4.4-4.9]}\end{array}$ & 3535 & $\begin{array}{c}6.2 \\
{[6.0-6.5]}\end{array}$ & 6230 & $\begin{array}{c}5.4 \\
{[5.3-5.6]}\end{array}$ \\
\hline $2015-2016$ & 2640 & $\begin{array}{c}4.5 \\
{[4.3-4.8]}\end{array}$ & 3425 & $\begin{array}{c}6.0 \\
{[5.7-6.2]}\end{array}$ & 6065 & $\begin{array}{c}5.2 \\
{[5.1-5.4]}\end{array}$ \\
\hline 2016-2017 & 2745 & $\begin{array}{c}4.6 \\
{[4.4-4.9]}\end{array}$ & 3600 & $\begin{array}{c}6.2 \\
{[5.9-6.5]}\end{array}$ & 6345 & $\begin{array}{c}5.4 \\
{[5.2-5.6]}\end{array}$ \\
\hline 2017-2018 & 2855 & $\begin{array}{c}4.8 \\
{[4.5-5.0]}\end{array}$ & 3575 & $\begin{array}{c}6.1 \\
{[5.8-6.3]}\end{array}$ & 6425 & $\begin{array}{c}5.4 \\
{[5.2-5.6]}\end{array}$ \\
\hline
\end{tabular}


Table S3c. Unadjusted annual recorded SRD diagnostic rates and raw counts, Ontario, 2001-2002 to 2017-2018

\begin{tabular}{|c|c|c|c|c|c|c|}
\hline & & nales & & Iales & & otal \\
\hline & $\mathrm{N}$ & $\begin{array}{c}\text { Unadjusted } \\
\text { rate }\end{array}$ & $\mathrm{N}$ & $\begin{array}{c}\text { Unadjusted } \\
\text { rate }\end{array}$ & $\mathrm{N}$ & $\begin{array}{c}\text { Unadjusted } \\
\text { rate }\end{array}$ \\
\hline 2001-2002 & 46090 & $\begin{array}{c}8.5 \\
{[8.4-8.6]}\end{array}$ & 76990 & $\begin{array}{c}14.7 \\
{[14.6-14.9]}\end{array}$ & 123080 & $\begin{array}{c}11.6 \\
{[11.5-11.7]}\end{array}$ \\
\hline $2002-2003$ & 46665 & $\begin{array}{c}8.5 \\
{[8.4-8.6]}\end{array}$ & 77615 & $\begin{array}{c}14.6 \\
{[14.4-14.7]}\end{array}$ & 124280 & $\begin{array}{c}11.5 \\
{[11.4-11.5]}\end{array}$ \\
\hline $2003-2004$ & 43130 & $\begin{array}{c}7.7 \\
{[7.6-7.8]}\end{array}$ & 74925 & $\begin{array}{c}13.8 \\
{[13.7-13.9]}\end{array}$ & 118055 & $\begin{array}{c}10.7 \\
{[10.6-10.8]}\end{array}$ \\
\hline 2004-2005 & 42840 & $\begin{array}{c}7.5 \\
{[7.4-7.6]}\end{array}$ & 76020 & $\begin{array}{c}13.7 \\
{[13.6-13.9]}\end{array}$ & 118865 & $\begin{array}{c}10.6 \\
{[10.5-10.6]}\end{array}$ \\
\hline $2005-2006$ & 45095 & $\begin{array}{c}7.8 \\
{[7.7-7.8]}\end{array}$ & 80360 & $\begin{array}{c}14.3 \\
{[14.2-14.4]}\end{array}$ & 125460 & $\begin{array}{c}11.0 \\
{[10.9-11.0]}\end{array}$ \\
\hline 2006-2007 & 46980 & $\begin{array}{c}8.1 \\
{[8.0-8.2]}\end{array}$ & 81155 & $\begin{array}{c}14.4 \\
{[14.3-14.6]}\end{array}$ & 128125 & $\begin{array}{c}11.2 \\
{[11.1-11.3]}\end{array}$ \\
\hline $2007-2008$ & 49715 & $\begin{array}{c}8.5 \\
{[8.4-8.6]}\end{array}$ & 84020 & $\begin{array}{c}14.9 \\
{[14.8-15.0]}\end{array}$ & 133740 & $\begin{array}{c}11.6 \\
{[11.6-11.7]}\end{array}$ \\
\hline 2008-2009 & 53405 & $\begin{array}{c}9.0 \\
{[8.9-9.1]}\end{array}$ & 89135 & $\begin{array}{c}15.7 \\
{[15.5-15.8]}\end{array}$ & 142540 & $\begin{array}{c}12.3 \\
{[12.2-12.4]}\end{array}$ \\
\hline $2009-2010$ & 52740 & $\begin{array}{c}8.8 \\
{[8.7-8.9]}\end{array}$ & 89990 & $\begin{array}{c}15.6 \\
{[15.5-15.7]}\end{array}$ & 142730 & $\begin{array}{c}12.1 \\
{[12.0-12.2]}\end{array}$ \\
\hline $2010-2011$ & 54390 & $\begin{array}{c}8.9 \\
{[8.8-9.0]}\end{array}$ & 93550 & $\begin{array}{c}16.0 \\
{[15.8-16.1]}\end{array}$ & 147940 & $\begin{array}{c}12.4 \\
{[12.3-12.5]}\end{array}$ \\
\hline 2011-2012 & 56350 & $\begin{array}{c}9.1 \\
{[9.0-9.2]}\end{array}$ & 97585 & $\begin{array}{c}16.4 \\
{[16.3-16.6]}\end{array}$ & 153930 & $\begin{array}{c}12.7 \\
{[12.6-12.8]}\end{array}$ \\
\hline $2012-2013$ & 57035 & $\begin{array}{c}9.1 \\
{[9.0-9.2]}\end{array}$ & 97130 & $\begin{array}{c}16.1 \\
{[16.0-16.2]}\end{array}$ & 154170 & $\begin{array}{c}12.5 \\
{[12.5-12.6]}\end{array}$ \\
\hline $2013-2014$ & 59135 & $\begin{array}{c}9.3 \\
{[9.2-9.4]}\end{array}$ & 101475 & $\begin{array}{c}16.6 \\
{[16.5-16.8]}\end{array}$ & 160610 & $\begin{array}{c}12.9 \\
{[12.8-13.0]}\end{array}$ \\
\hline 2014-2015 & 60330 & $\begin{array}{c}9.5 \\
{[9.4-9.6]}\end{array}$ & 104035 & $\begin{array}{c}16.9 \\
{[16.8-17.1]}\end{array}$ & 164370 & $\begin{array}{c}13.1 \\
{[13.0-13.2]}\end{array}$ \\
\hline $2015-2016$ & 62860 & $\begin{array}{c}9.7 \\
{[9.6-9.8]}\end{array}$ & 108855 & $\begin{array}{c}17.5 \\
{[17.4-17.6]}\end{array}$ & 171720 & $\begin{array}{c}13.6 \\
{[13.5-13.6]}\end{array}$ \\
\hline 2016-2017 & 65590 & $\begin{array}{c}10.0 \\
{[9.9-10.1]}\end{array}$ & 113650 & $\begin{array}{c}18.0 \\
{[17.9-18.1]}\end{array}$ & 179240 & $\begin{array}{c}13.9 \\
{[13.9-14.0]}\end{array}$ \\
\hline 2017-2018 & 68905 & $\begin{array}{c}10.4 \\
{[10.3-10.5]}\end{array}$ & 118920 & $\begin{array}{c}18.6 \\
{[18.4-18.7]}\end{array}$ & 187825 & $\begin{array}{c}14.4 \\
{[14.3-14.5]}\end{array}$ \\
\hline
\end{tabular}


Table S3d. Unadjusted annual recorded SRD diagnostic rates and raw counts, Québec, 2001-2002 to 2017-2018

\begin{tabular}{|c|c|c|c|c|c|c|}
\hline & \multicolumn{2}{|c|}{ Females } & \multicolumn{2}{|c|}{ Males } & \multicolumn{2}{|c|}{ Total } \\
\hline & $\mathrm{N}$ & $\begin{array}{l}\text { Unadjusted } \\
\text { rate }\end{array}$ & $\mathrm{N}$ & $\begin{array}{l}\text { Unadjusted } \\
\text { rate }\end{array}$ & $\mathrm{N}$ & $\begin{array}{l}\text { Unadjusted } \\
\text { rate }\end{array}$ \\
\hline 2001-2002 & 16535 & $\begin{array}{c}5.1 \\
{[5.0-5.2]}\end{array}$ & 31185 & $\begin{array}{c}10.0 \\
{[9.9-10.1]}\end{array}$ & 47720 & $\begin{array}{c}7.5 \\
{[7.4-7.6]}\end{array}$ \\
\hline $2002-2003$ & 16180 & $\begin{array}{c}4.9 \\
{[4.8-5.0]}\end{array}$ & 30220 & $\begin{array}{c}9.6 \\
{[9.5-9.7]}\end{array}$ & 46400 & $\begin{array}{c}7.2 \\
{[7.1-7.3]}\end{array}$ \\
\hline 2003-2004 & 16725 & $\begin{array}{c}5.0 \\
{[4.9-5.1]}\end{array}$ & 31215 & $\begin{array}{c}9.8 \\
{[9.7-10.0]}\end{array}$ & 47940 & $\begin{array}{c}7.4 \\
{[7.3-7.5]}\end{array}$ \\
\hline 2004-2005 & 16615 & $\begin{array}{c}5.0 \\
{[4.9-5.1]}\end{array}$ & 32080 & $\begin{array}{c}10.0 \\
{[9.8-10.1]}\end{array}$ & 48690 & $\begin{array}{c}7.4 \\
{[7.3-7.5]}\end{array}$ \\
\hline $2005-2006$ & 17555 & $\begin{array}{c}5.2 \\
{[5.1-5.3]}\end{array}$ & 33900 & $\begin{array}{c}10.4 \\
{[10.3-10.6]}\end{array}$ & 51455 & $\begin{array}{c}7.8 \\
{[7.7-7.9]}\end{array}$ \\
\hline 2006-2007 & 18640 & $\begin{array}{c}5.5 \\
{[5.4-5.6]}\end{array}$ & 35815 & $\begin{array}{c}10.9 \\
{[10.8-11.1]}\end{array}$ & 54450 & $\begin{array}{c}8.1 \\
{[8.1-8.2]}\end{array}$ \\
\hline $2007-2008$ & 19410 & $\begin{array}{c}5.6 \\
{[5.5-5.8]}\end{array}$ & 36805 & $\begin{array}{c}11.2 \\
{[11.0-11.3]}\end{array}$ & 56220 & $\begin{array}{c}8.3 \\
{[8.3-8.4]}\end{array}$ \\
\hline 2008-2009 & 19730 & $\begin{array}{c}5.7 \\
{[5.6-5.8]}\end{array}$ & 37400 & $\begin{array}{c}11.3 \\
{[11.1-11.4]}\end{array}$ & 57135 & $\begin{array}{c}8.4 \\
{[8.3-8.5]}\end{array}$ \\
\hline 2009-2010 & 19930 & $\begin{array}{c}5.7 \\
{[5.6-5.8]}\end{array}$ & 37885 & $\begin{array}{c}11.3 \\
{[11.1-11.4]}\end{array}$ & 57810 & $\begin{array}{c}8.4 \\
{[8.4-8.5]}\end{array}$ \\
\hline $2010-2011$ & 20000 & $\begin{array}{c}5.7 \\
{[5.6-5.8]}\end{array}$ & 37615 & $\begin{array}{c}11.1 \\
{[11.0-11.3]}\end{array}$ & 57615 & $\begin{array}{c}8.4 \\
{[8.3-8.4]}\end{array}$ \\
\hline 2011-2012 & 20550 & $\begin{array}{c}5.8 \\
{[5.7-5.9]}\end{array}$ & 38475 & $\begin{array}{c}11.3 \\
{[11.1-11.4]}\end{array}$ & 59025 & $\begin{array}{c}8.5 \\
{[8.4-8.6]}\end{array}$ \\
\hline $2012-2013$ & 21125 & $\begin{array}{c}5.9 \\
{[5.8-6.0]}\end{array}$ & 39095 & $\begin{array}{c}11.4 \\
{[11.2-11.5]}\end{array}$ & 60220 & $\begin{array}{c}8.6 \\
{[8.5-8.7]}\end{array}$ \\
\hline 2013-2014 & 21125 & $\begin{array}{c}5.9 \\
{[5.8-6.0]}\end{array}$ & 38670 & $\begin{array}{c}11.2 \\
{[11.0-11.3]}\end{array}$ & 59790 & $\begin{array}{c}8.5 \\
{[8.4-8.6]}\end{array}$ \\
\hline 2014-2015 & 21360 & $\begin{array}{c}5.9 \\
{[5.8-6.0]}\end{array}$ & 38675 & $\begin{array}{c}11.1 \\
{[11.0-11.3]}\end{array}$ & 60040 & $\begin{array}{c}8.5 \\
{[8.4-8.6]}\end{array}$ \\
\hline $2015-2016$ & 21080 & $\begin{array}{c}5.8 \\
{[5.7-5.9]}\end{array}$ & 38450 & $\begin{array}{c}11.0 \\
{[10.8-11.1]}\end{array}$ & 59530 & $\begin{array}{c}8.4 \\
{[8.3-8.4]}\end{array}$ \\
\hline 2016-2017 & 21395 & $\begin{array}{c}5.9 \\
{[5.8-6.0]}\end{array}$ & 38170 & $\begin{array}{c}10.8 \\
{[10.7-11.0]}\end{array}$ & 59565 & $\begin{array}{c}8.3 \\
{[8.2-8.4]}\end{array}$ \\
\hline $2017-2018$ & 19610 & $\begin{array}{c}5.4 \\
{[5.3-5.5]}\end{array}$ & 35395 & $\begin{array}{c}10.0 \\
{[9.8-10.1]}\end{array}$ & 55010 & $\begin{array}{c}7.6 \\
{[7.5-7.7]}\end{array}$ \\
\hline
\end{tabular}


Table S3e. Unadjusted annual recorded SRD diagnostic rates and raw counts, Nova Scotia, 2001-2002 to 2017-2018

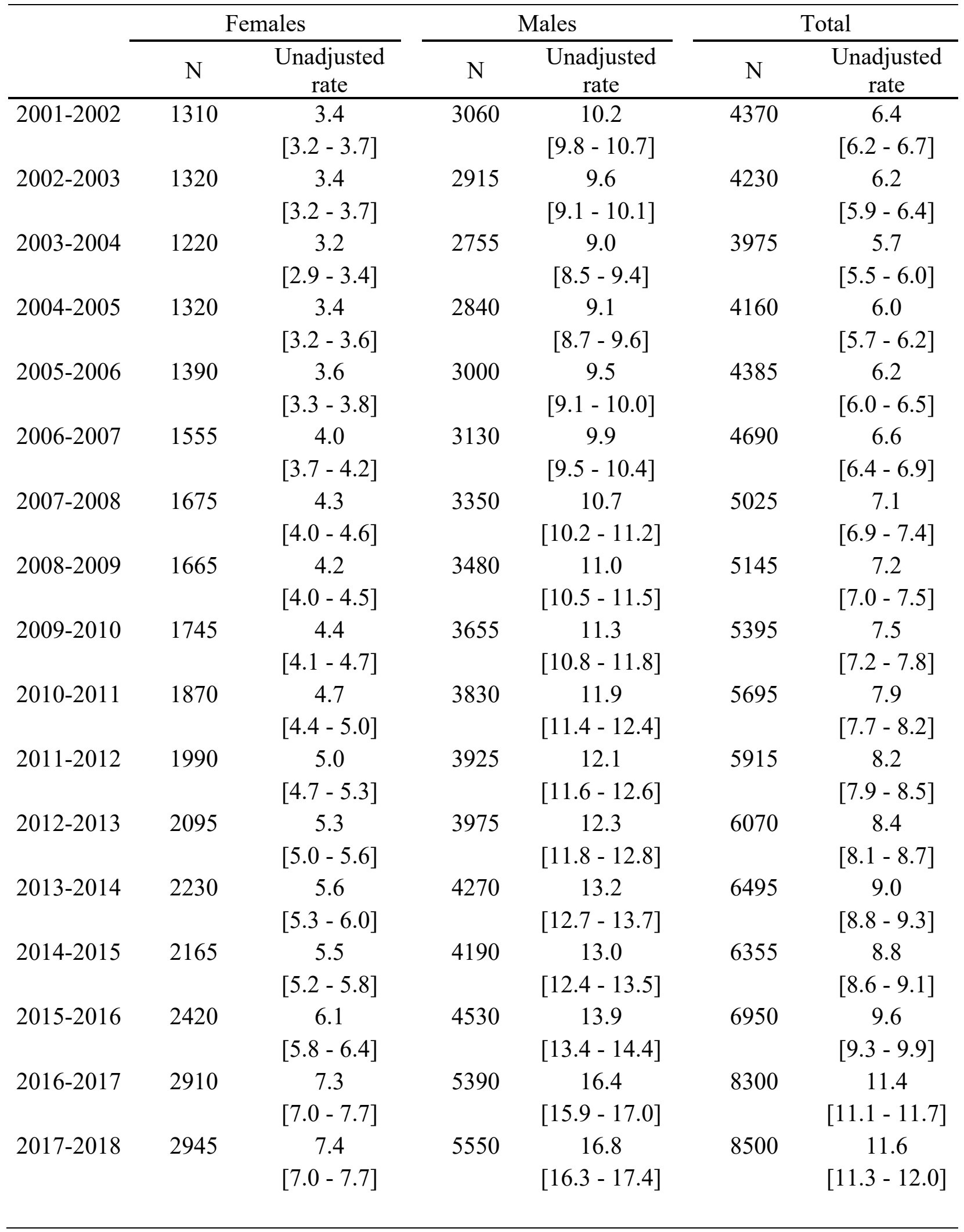


Table S4a. Age-adjusted and unadjusted mortality rates among cumulative recorded SRD diagnosed cases and non-recorded SRD

cases, Alberta, 2015-2016, by cause of death

\begin{tabular}{|c|c|c|c|c|c|c|}
\hline & \multicolumn{3}{|c|}{ Recorded SRD diagnosis } & \multicolumn{3}{|c|}{ No recorded SRD diagnosis } \\
\hline & $\mathrm{N}$ & $\begin{array}{l}\text { Age-adjusted } \\
\text { mortality rate } \\
\text { (per } 100,000)\end{array}$ & $\begin{array}{c}\text { Unadjusted } \\
\text { mortality rate } \\
\text { (per } 100,000)\end{array}$ & $\mathrm{N}$ & $\begin{array}{l}\text { Age-adjusted } \\
\text { mortality rate } \\
\text { (per } 100,000)\end{array}$ & $\begin{array}{c}\text { Unadjusted } \\
\text { mortality rate } \\
\text { (per 100,000) }\end{array}$ \\
\hline Neoplasms & 740 & $\begin{array}{c}375.7 \\
{[340.3-413.9]}\end{array}$ & $\begin{array}{c}317.8 \\
{[288.5-349.1]}\end{array}$ & 5650 & $\begin{array}{c}186.9 \\
{[180.6-193.5]}\end{array}$ & $\begin{array}{c}157.2 \\
{[151.8-162.6]}\end{array}$ \\
\hline Diseases of the circulatory system & 905 & $\begin{array}{c}472.8 \\
{[432.5-515.8]}\end{array}$ & $\begin{array}{c}388.6 \\
{[356.2-423.2]}\end{array}$ & 5880 & $\begin{array}{c}198.0 \\
{[191.4-204.8]}\end{array}$ & $\begin{array}{c}163.6 \\
{[158.1-169.1]}\end{array}$ \\
\hline Dementia & 245 & $\begin{array}{c}141.9 \\
{[119.5-167.4]}\end{array}$ & $\begin{array}{c}105.2 \\
{[88.7-123.8]}\end{array}$ & 1335 & $\begin{array}{c}45.8 \\
{[42.6-49.1]}\end{array}$ & $\begin{array}{c}37.1 \\
{[34.6-39.8]}\end{array}$ \\
\hline Diseases of the digestive system & 215 & $\begin{array}{c}100.1 \\
{[82.9-120.0]}\end{array}$ & $\begin{array}{c}92.3 \\
{[76.9-109.8]}\end{array}$ & 585 & $\begin{array}{c}19.9 \\
{[17.9-22.1]}\end{array}$ & $\begin{array}{c}16.3 \\
{[14.6-18.1]}\end{array}$ \\
\hline Endocrine, nutritional, and metabolic diseases & 110 & $\begin{array}{c}53.7 \\
{[41.0-69.2]}\end{array}$ & $\begin{array}{c}47.2 \\
{[36.4-60.1]}\end{array}$ & 610 & $\begin{array}{c}20.3 \\
{[18.2-22.5]}\end{array}$ & $\begin{array}{c}17.0 \\
{[15.3-18.8]}\end{array}$ \\
\hline Infectious and parasitic diseases & 95 & $\begin{array}{c}46.6 \\
{[35.1-61.0]}\end{array}$ & $\begin{array}{c}40.8 \\
{[30.8-52.9]}\end{array}$ & 325 & $\begin{array}{c}10.9 \\
{[9.4-12.5]}\end{array}$ & $\begin{array}{c}9.0 \\
{[7.8-10.4]}\end{array}$ \\
\hline Diseases of the nervous system & 130 & $\begin{array}{c}68.7 \\
{[53.9-86.5]}\end{array}$ & $\begin{array}{c}55.8 \\
{[44.0-69.7]}\end{array}$ & 720 & $\begin{array}{c}24.1 \\
{[21.8-26.5]}\end{array}$ & $\begin{array}{c}20.0 \\
{[18.2-22.0]}\end{array}$ \\
\hline Diseases of the respiratory system & 390 & $\begin{array}{c}200.8 \\
{[175.1-229.4]}\end{array}$ & $\begin{array}{c}167.5 \\
{[146.4-190.6]}\end{array}$ & 1660 & $\begin{array}{c}56.2 \\
{[52.7-59.9]}\end{array}$ & $\begin{array}{c}46.2 \\
{[43.3-49.2]}\end{array}$ \\
\hline Substance-related disorders & 335 & $\begin{array}{c}142.2 \\
{[122.5-164.5]}\end{array}$ & $\begin{array}{c}143.9 \\
{[124.4-165.4]}\end{array}$ & 55 & $\begin{array}{c}1.6 \\
{[1.1-2.3]}\end{array}$ & $\begin{array}{c}1.5 \\
{[1.1-2.1]}\end{array}$ \\
\hline Suicide & 230 & $\begin{array}{c}98.8 \\
{[82.2-118.1]}\end{array}$ & $\begin{array}{c}98.8 \\
{[82.8-116.8]}\end{array}$ & 360 & $\begin{array}{c}10.2 \\
{[8.9-11.7]}\end{array}$ & $\begin{array}{c}10.0 \\
{[8.7-11.5]}\end{array}$ \\
\hline Trauma (excluding suicide) & 600 & $\begin{array}{c}251.7 \\
{[224.9-281.1]}\end{array}$ & $\begin{array}{c}257.7 \\
{[231.4-286.0]}\end{array}$ & 930 & {$[27.7$} & $\begin{array}{c}25.9 \\
{[23.7-28.1]}\end{array}$ \\
\hline Other causes & 115 & $\begin{array}{c}63.2 \\
{[48.9-80.6]}\end{array}$ & $\begin{array}{c}49.4 \\
{[38.3-62.5]}\end{array}$ & 745 & $\begin{array}{c}25.0 \\
{[22.7-27.4]}\end{array}$ & $\begin{array}{c}20.7 \\
{[18.8-22.8]}\end{array}$ \\
\hline Unknown causes & 105 & $\begin{array}{c}45.7 \\
{[34.8-59.3]}\end{array}$ & $\begin{array}{c}45.1 \\
{[34.6-57.7]}\end{array}$ & 380 & $\begin{array}{c}12.1 \\
{[10.5-13.8]}\end{array}$ & $\begin{array}{c}10.6 \\
{[9.2-12.0]}\end{array}$ \\
\hline
\end{tabular}


Table S4b. Age-adjusted and unadjusted mortality rates among cumulative recorded SRD diagnosed cases and non-recorded SRD

cases, Manitoba, 2015-2016, by cause of death

\begin{tabular}{|c|c|c|c|c|c|c|}
\hline & \multicolumn{3}{|c|}{ Recorded SRD diagnosis } & \multicolumn{3}{|c|}{ No recorded SRD diagnosis } \\
\hline & $\mathrm{N}$ & $\begin{array}{l}\text { Age-adjusted } \\
\text { mortality rate } \\
\text { (per } 100,000)\end{array}$ & $\begin{array}{c}\text { Unadjusted } \\
\text { mortality rate } \\
\text { (per } 100,000)\end{array}$ & $\mathrm{N}$ & $\begin{array}{l}\text { Age-adjusted } \\
\text { mortality rate } \\
\text { (per } 100,000)\end{array}$ & $\begin{array}{c}\text { Unadjusted } \\
\text { mortality rate } \\
\text { (per 100,000) }\end{array}$ \\
\hline Neoplasms & 185 & $\begin{array}{c}438.2 \\
{[358.3-534.1]}\end{array}$ & $\begin{array}{c}399.7 \\
{[328.1-481.8]}\end{array}$ & 2605 & $\begin{array}{c}232.8 \\
{[221.2-244.8]}\end{array}$ & $\begin{array}{c}234.4 \\
{[222.7-246.5]}\end{array}$ \\
\hline Diseases of the circulatory system & 175 & $\begin{array}{c}421.7 \\
{[343.0-516.4]}\end{array}$ & $\begin{array}{c}378.1 \\
{[308.5-458.1]}\end{array}$ & 2665 & $\begin{array}{c}235.3 \\
{[223.7-247.3]}\end{array}$ & $\begin{array}{c}239.8 \\
{[228.0-252.0]}\end{array}$ \\
\hline Dementia & 40 & $\begin{array}{c}99.6 \\
{[62.6-154.4]}\end{array}$ & $\begin{array}{c}86.4 \\
{[55.3-128.2]}\end{array}$ & 725 & $\begin{array}{c}63.2 \\
{[57.3-69.5]}\end{array}$ & $\begin{array}{c}65.2 \\
{[59.2-71.7]}\end{array}$ \\
\hline Diseases of the digestive system & 45 & $\begin{array}{c}101.5 \\
{[66.1-153.9]}\end{array}$ & $\begin{array}{c}97.2 \\
{[63.9-141.2]}\end{array}$ & 285 & $\begin{array}{c}25.1 \\
{[21.4-29.2]}\end{array}$ & $\begin{array}{c}25.6 \\
{[21.9-29.8]}\end{array}$ \\
\hline Endocrine, nutritional, and metabolic diseases & 30 & $\begin{array}{c}69.5 \\
{[41.0-115.5]}\end{array}$ & $\begin{array}{c}64.8 \\
{[38.4-102.0]}\end{array}$ & 410 & $\begin{array}{c}36.5 \\
{[32.0-41.4]}\end{array}$ & $\begin{array}{c}36.9 \\
{[32.4-41.8]}\end{array}$ \\
\hline Infectious and parasitic diseases & 25 & $\begin{array}{c}48.9 \\
{[27.0-88.1]}\end{array}$ & $\begin{array}{c}54.0 \\
{[30.2-88.6]}\end{array}$ & 135 & $\begin{array}{c}12.0 \\
{[9.5-14.9]}\end{array}$ & {$[9.6-15.1]$} \\
\hline Diseases of the nervous system & 15 & $\begin{array}{c}31.3 \\
{[14.1-67.2]}\end{array}$ & $\begin{array}{c}32.4 \\
{[14.9-60.8]}\end{array}$ & 355 & $\begin{array}{c}31.5 \\
{[27.4-36.1]}\end{array}$ & $\begin{array}{c}31.9 \\
{[27.7-36.6]}\end{array}$ \\
\hline Diseases of the respiratory system & 80 & $\begin{array}{c}191.3 \\
{[139.8-259.4]}\end{array}$ & $\begin{array}{c}172.8 \\
{[127.1-229.1]}\end{array}$ & 800 & $\begin{array}{c}70.7 \\
{[64.4-77.4]}\end{array}$ & $\begin{array}{c}72.0 \\
{[65.6-78.8]}\end{array}$ \\
\hline Substance-related disorders & 70 & $\begin{array}{c}136.8 \\
{[97.7-191.4]}\end{array}$ & $\begin{array}{c}151.2 \\
{[108.7-204.3]}\end{array}$ & 40 & $\begin{array}{c}3.7 \\
{[2.3-5.4]}\end{array}$ & $\begin{array}{c}3.6 \\
{[2.3-5.3]}\end{array}$ \\
\hline Suicide & 40 & {$[65.1-163.5]$} & $\begin{array}{c}86.4 \\
{[55.3-128.3]}\end{array}$ & 140 & $\begin{array}{c}12.6 \\
{[10.0-15.6]}\end{array}$ & $\begin{array}{c}12.6 \\
{[10.0-15.6]}\end{array}$ \\
\hline Trauma (excluding suicide) & 140 & $\begin{array}{c}320.1 \\
{[247.4-410.4]}\end{array}$ & $\begin{array}{c}302.5 \\
{[240.7-374.8]}\end{array}$ & 460 & $\begin{array}{c}40.8 \\
{[36.1-46.0]}\end{array}$ & $\begin{array}{c}41.4 \\
{[36.6-46.6]}\end{array}$ \\
\hline Other causes & 60 & $\begin{array}{c}131.5 \\
{[90.4-189.2]}\end{array}$ & $\begin{array}{c}129.6 \\
{[90.6-179.3]}\end{array}$ & 650 & $\begin{array}{c}57.4 \\
{[51.7-63.5]}\end{array}$ & $\begin{array}{c}58.5 \\
{[52.7-64.7]}\end{array}$ \\
\hline
\end{tabular}


Table S4c. Age-adjusted and unadjusted mortality rates among cumulative recorded SRD diagnosed cases and non-recorded SRD

cases, Ontario, 2015-2016, by cause of death

\begin{tabular}{|c|c|c|c|c|c|c|}
\hline & \multicolumn{3}{|c|}{ Recorded SRD diagnosis } & \multicolumn{3}{|c|}{ No recorded SRD diagnosis } \\
\hline & $\mathrm{N}$ & $\begin{array}{l}\text { Age-adjusted } \\
\text { mortality rate } \\
\text { (per } 100,000)\end{array}$ & $\begin{array}{c}\text { Unadjusted } \\
\text { mortality rate } \\
\text { (per 100,000) }\end{array}$ & $\mathrm{N}$ & $\begin{array}{l}\text { Age-adjusted } \\
\text { mortality rate } \\
\text { (per } 100,000)\end{array}$ & $\begin{array}{c}\text { Unadjusted } \\
\text { mortality rate } \\
\text { (per } 100,000)\end{array}$ \\
\hline Neoplasms & 4240 & $\begin{array}{c}364.0 \\
{[349.7-378.9]}\end{array}$ & $\begin{array}{c}407.4 \\
{[391.4-423.8]}\end{array}$ & 21865 & $\begin{array}{c}177.6 \\
{[174.5-180.7]}\end{array}$ & $\begin{array}{c}188.0 \\
{[184.7-191.3]}\end{array}$ \\
\hline Diseases of the circulatory system & 4075 & $\begin{array}{c}355.2 \\
{[340.9-370.1]}\end{array}$ & $\begin{array}{c}391.5 \\
{[375.9-407.6]}\end{array}$ & 19730 & $\begin{array}{c}157.9 \\
{[155.0-160.8]}\end{array}$ & $\begin{array}{c}169.6 \\
{[166.5-172.8]}\end{array}$ \\
\hline Dementia & 1110 & $\begin{array}{c}100.3 \\
{[92.7-108.5]}\end{array}$ & $\begin{array}{c}106.6 \\
{[98.6-115.2]}\end{array}$ & 4440 & $\begin{array}{c}35.1 \\
{[33.7-36.4]}\end{array}$ & $\begin{array}{c}38.2 \\
{[36.7-39.7]}\end{array}$ \\
\hline Diseases of the digestive system & 940 & $\begin{array}{c}79.8 \\
{[73.3-87.0]}\end{array}$ & $\begin{array}{c}90.3 \\
{[82.9-98.2]}\end{array}$ & 2385 & $\begin{array}{c}19.1 \\
{[18.1-20.2]}\end{array}$ & $\begin{array}{c}20.5 \\
{[19.4-21.6]}\end{array}$ \\
\hline Endocrine, nutritional, and metabolic diseases & 565 & $\begin{array}{c}48.5 \\
{[43.4-54.2]}\end{array}$ & $\begin{array}{c}54.3 \\
{[48.6-60.4]}\end{array}$ & 2300 & $\begin{array}{c}18.6 \\
{[17.6-19.6]}\end{array}$ & $\begin{array}{c}19.8 \\
{[18.7-20.9]}\end{array}$ \\
\hline Infectious and parasitic diseases & 520 & $\begin{array}{c}43.9 \\
{[39.1-49.3]}\end{array}$ & $\begin{array}{c}50.0 \\
{[44.5-55.9]}\end{array}$ & 1445 & $\begin{array}{c}11.6 \\
{[10.8-12.4]}\end{array}$ & $\begin{array}{c}12.4 \\
{[11.6-13.3]}\end{array}$ \\
\hline Diseases of the nervous system & 590 & $\begin{array}{c}52.2 \\
{[46.8-58.2]}\end{array}$ & $\begin{array}{c}56.7 \\
{[50.9-63.0]}\end{array}$ & 2960 & $\begin{array}{c}23.7 \\
{[22.6-24.9]}\end{array}$ & $\begin{array}{c}25.4 \\
{[24.3-26.7]}\end{array}$ \\
\hline Diseases of the respiratory system & 2085 & $\begin{array}{c}182.7 \\
{[172.5-193.4]}\end{array}$ & $\begin{array}{c}200.3 \\
{[189.2-211.9]}\end{array}$ & 7550 & $\begin{array}{c}60.1 \\
{[58.4-62.0]}\end{array}$ & $\begin{array}{c}64.9 \\
{[63.0-66.9]}\end{array}$ \\
\hline Substance-related disorders & 920 & $\begin{array}{c}76.6 \\
{[70.1-83.7]}\end{array}$ & $\begin{array}{c}88.4 \\
{[81.1-96.2]}\end{array}$ & 100 & $\begin{array}{c}0.9 \\
{[0.6-1.1]}\end{array}$ & $\begin{array}{c}0.9 \\
{[0.7-1.1]}\end{array}$ \\
\hline Suicide & 445 & $\begin{array}{c}44.3 \\
{[38.6-50.8]}\end{array}$ & $\begin{array}{c}42.8 \\
{[37.7-48.3]}\end{array}$ & 845 & $\begin{array}{c}7.2 \\
{[6.6-7.9]}\end{array}$ & $\begin{array}{c}7.3 \\
{[6.6-7.9]}\end{array}$ \\
\hline Trauma (excluding suicide) & 1530 & $\begin{array}{c}141.6 \\
{[131.9-151.9]}\end{array}$ & $\begin{array}{c}147.0 \\
{[137.5-157.0]}\end{array}$ & 3355 & $\begin{array}{c}27.3 \\
{[26.1-28.5]}\end{array}$ & $\begin{array}{c}28.8 \\
{[27.6-30.2]}\end{array}$ \\
\hline
\end{tabular}




\begin{tabular}{|c|c|c|c|c|c|c|}
\hline Other causes & 1600 & $\begin{array}{c}141.6 \\
{[132.5-151.3]}\end{array}$ & $\begin{array}{c}153.7 \\
{[144.0-163.9]}\end{array}$ & 6210 & $\begin{array}{c}49.7 \\
{[48.1-51.4]}\end{array}$ & $\begin{array}{c}53.4 \\
{[51.7-55.2]}\end{array}$ \\
\hline Unknown causes & 580 & $\begin{array}{c}50.1 \\
{[44.9-56.0]}\end{array}$ & $\begin{array}{c}55.7 \\
{[49.9-62.0]}\end{array}$ & 2815 & $\begin{array}{c}22.7 \\
{[21.6-23.8]}\end{array}$ & $\begin{array}{c}24.2 \\
{[23.0-25.4]}\end{array}$ \\
\hline
\end{tabular}

Table S4d. Age-adjusted and unadjusted mortality rates among cumulative recorded SRD diagnosed cases and non-recorded SRD

cases, Québec, 2015-2016, by cause of death

\begin{tabular}{|c|c|c|c|c|c|c|}
\hline & \multicolumn{3}{|c|}{ Recorded SRD diagnosis } & \multicolumn{3}{|c|}{ No recorded SRD diagnosis } \\
\hline & $\mathrm{N}$ & $\begin{array}{l}\text { Age-adjusted } \\
\text { mortality rate } \\
\text { (per } 100,000)\end{array}$ & $\begin{array}{c}\text { Unadjusted } \\
\text { mortality rate } \\
\text { (per } 100,000)\end{array}$ & $\mathrm{N}$ & $\begin{array}{l}\text { Age-adjusted } \\
\text { mortality rate } \\
\text { (per } 100,000)\end{array}$ & $\begin{array}{c}\text { Unadjusted } \\
\text { mortality rate } \\
\text { (per } 100,000)\end{array}$ \\
\hline Neoplasms & 2945 & $\begin{array}{c}585.9 \\
{[558.4-614.8]}\end{array}$ & $\begin{array}{c}744.3 \\
{[709.4-780.3]}\end{array}$ & 18035 & $\begin{array}{c}231.8 \\
{[227.4-236.3]}\end{array}$ & $\begin{array}{c}268.2 \\
{[263.1-273.4]}\end{array}$ \\
\hline Diseases of the circulatory system & 2320 & $\begin{array}{c}459.2 \\
{[435.0-484.8]}\end{array}$ & $\begin{array}{c}586.3 \\
{[555.4-618.4]}\end{array}$ & 12620 & $\begin{array}{c}158.8 \\
{[155.1-162.5]}\end{array}$ & $\begin{array}{c}187.7 \\
{[183.4-192.0]}\end{array}$ \\
\hline Dementia & 735 & $\begin{array}{c}143.2 \\
{[130.0-157.8]}\end{array}$ & $\begin{array}{c}185.8 \\
{[168.6-204.1]}\end{array}$ & 2465 & $\begin{array}{c}30.5 \\
{[28.9-32.1]}\end{array}$ & $\begin{array}{c}36.7 \\
{[34.8-38.6]}\end{array}$ \\
\hline Diseases of the digestive system & 600 & $\begin{array}{c}120.3 \\
{[108.0-134.1]}\end{array}$ & $\begin{array}{c}151.6 \\
{[136.2-168.3]}\end{array}$ & 1580 & $\begin{array}{c}19.9 \\
{[18.6-21.2]}\end{array}$ & $\begin{array}{c}23.5 \\
{[22.0-25.1]}\end{array}$ \\
\hline Endocrine, nutritional, and metabolic diseases & 370 & $\begin{array}{c}74.6 \\
{[64.8-85.9]}\end{array}$ & $\begin{array}{c}93.5 \\
{[81.5-106.8]}\end{array}$ & 1555 & $\begin{array}{c}19.7 \\
{[18.4-21.0]}\end{array}$ & $\begin{array}{c}23.1 \\
{[21.6-24.7]}\end{array}$ \\
\hline Infectious and parasitic diseases & 255 & $\begin{array}{c}51.3 \\
{[43.3-60.7]}\end{array}$ & $\begin{array}{c}64.4 \\
{[54.5-75.6]}\end{array}$ & 885 & $\begin{array}{c}11.2 \\
{[10.2-12.2]}\end{array}$ & $\begin{array}{c}13.2 \\
{[12.0-14.3]}\end{array}$ \\
\hline Diseases of the nervous system & 675 & $\begin{array}{c}133.2 \\
{[120.3-147.5]}\end{array}$ & $\begin{array}{c}170.6 \\
{[154.2-188.2]}\end{array}$ & 3445 & $\begin{array}{c}43.4 \\
{[41.5-45.3]}\end{array}$ & $\begin{array}{c}51.2 \\
{[49.0-53.5]}\end{array}$ \\
\hline Diseases of the respiratory system & 1235 & $\begin{array}{c}242.5 \\
{[225.1-261.4]}\end{array}$ & $\begin{array}{c}312.1 \\
{[289.7-335.7]}\end{array}$ & 4600 & $\begin{array}{c}57.5 \\
{[55.3-59.7]}\end{array}$ & $\begin{array}{c}68.4 \\
{[65.8-71.0]}\end{array}$ \\
\hline Substance-related disorders & 350 & $\begin{array}{c}71.8 \\
{[62.2-82.8]}\end{array}$ & $\begin{array}{c}88.5 \\
{[76.8-101.4]}\end{array}$ & 35 & $\begin{array}{c}0.4 \\
{[0.3-0.7]}\end{array}$ & $\begin{array}{c}0.5 \\
{[0.3-0.8]}\end{array}$ \\
\hline Suicide & 350 & $\begin{array}{c}88.5 \\
{[76.1-102.6]}\end{array}$ & $\begin{array}{c}88.5 \\
{[76.8-101.4]}\end{array}$ & 680 & $\begin{array}{c}10.0 \\
{[9.0-11.0]}\end{array}$ & $\begin{array}{c}10.1 \\
{[9.1-11.2]}\end{array}$ \\
\hline
\end{tabular}




\begin{tabular}{|c|c|c|c|c|c|c|}
\hline Trauma (excluding suicide) & 600 & $\begin{array}{c}134.9 \\
{[120.6-150.8]}\end{array}$ & $\begin{array}{c}151.6 \\
{[136.2-168.3]}\end{array}$ & 1755 & $\begin{array}{c}23.3 \\
{[21.9-24.8]}\end{array}$ & $\begin{array}{c}26.1 \\
{[24.5-27.7]}\end{array}$ \\
\hline Other causes & 490 & $\begin{array}{c}97.6 \\
{[86.6-110.1]}\end{array}$ & $\begin{array}{c}123.8 \\
{[109.9-139.0]}\end{array}$ & 2130 & $\begin{array}{c}26.9 \\
{[25.4-28.5]}\end{array}$ & $\begin{array}{c}31.7 \\
{[29.9-33.5]}\end{array}$ \\
\hline Unknown causes & 270 & $\begin{array}{c}59.0 \\
{[49.8-69.7]}\end{array}$ & $\begin{array}{c}68.2 \\
{[58.0-79.7]}\end{array}$ & 1475 & $\begin{array}{c}19.1 \\
{[17.9-20.5]}\end{array}$ & $\begin{array}{c}21.9 \\
{[20.5-23.4]}\end{array}$ \\
\hline
\end{tabular}

Table S4e. Age-adjusted and unadjusted mortality rates among cumulative recorded SRD diagnosed cases and non-recorded SRD

cases, Nova Scotia, 2015-2016, by cause of death

\begin{tabular}{|c|c|c|c|c|c|c|}
\hline & \multicolumn{3}{|c|}{ Recorded SRD diagnosis } & \multicolumn{3}{|c|}{ No recorded SRD diagnosis } \\
\hline & $\mathrm{N}$ & $\begin{array}{l}\text { Age-adjusted } \\
\text { mortality rate } \\
\text { (per } 100,000)\end{array}$ & $\begin{array}{c}\text { Unadjusted } \\
\text { mortality rate } \\
(\text { per } 100,000)\end{array}$ & $\mathrm{N}$ & $\begin{array}{c}\text { Age-adjusted } \\
\text { mortality rate (per } \\
100,000)\end{array}$ & $\begin{array}{c}\text { Unadjusted } \\
\text { mortality rate } \\
(\text { per } 100,000)\end{array}$ \\
\hline Neoplasms & 150 & $\begin{array}{c}2530.1 \\
{[1803.0-4816.9]}\end{array}$ & $\begin{array}{c}4189.9 \\
{[3361.2-5154.4]}\end{array}$ & 1745 & $\begin{array}{c}7267.4 \\
{[5857.1-9037.1]}\end{array}$ & $\begin{array}{c}6097.1 \\
{[5727.7-6483.3]}\end{array}$ \\
\hline Diseases of the circulatory system & 125 & $\begin{array}{c}1930.0 \\
{[1270.6-4230.8]}\end{array}$ & $\begin{array}{c}3486.8 \\
{[2735.9-4373.4]}\end{array}$ & 1325 & $\begin{array}{c}2831.9 \\
{[2237.0-3751.2]}\end{array}$ & $\begin{array}{c}4629.6 \\
{[4308.6-4967.4]}\end{array}$ \\
\hline Dementia & 25 & $\begin{array}{c}217.6 \\
{[124.8-2718.0]}\end{array}$ & $\begin{array}{c}698.3 \\
{[390.9-1145.3]}\end{array}$ & 440 & $\begin{array}{c}311.4 \\
{[274.5-892.0]}\end{array}$ & $\begin{array}{c}1537.4 \\
{[1355.2-1736.4]}\end{array}$ \\
\hline Diseases of the digestive system & 75 & $\begin{array}{c}1572.1 \\
{[938.3-3910.8]}\end{array}$ & $\begin{array}{c}2092.1 \\
{[1522.2-2798.6]}\end{array}$ & 195 & $\begin{array}{c}257.7 \\
{[184.2-859.4]}\end{array}$ & $\begin{array}{c}681.3 \\
{[562.2-817.4]}\end{array}$ \\
\hline Endocrine, nutritional, and metabolic diseases & 25 & $\begin{array}{c}344.5 \\
{[173.6-2775.7]}\end{array}$ & $\begin{array}{c}697.4 \\
{[390.4-1143.7]}\end{array}$ & 210 & $\begin{array}{c}586.1 \\
{[337.4-1268.0]}\end{array}$ & $\begin{array}{c}733.8 \\
{[609.9-874.5]}\end{array}$ \\
\hline Infectious and parasitic diseases & 10 & $\begin{array}{c}225.2 \\
{[83.7-2735.4]}\end{array}$ & $\begin{array}{c}278.9 \\
{[103.7-596.9]}\end{array}$ & 100 & $\begin{array}{c}1069.4 \\
{[410.0-2326.1]}\end{array}$ & $\begin{array}{c}349.4 \\
{[266.0-449.9]}\end{array}$ \\
\hline Diseases of the nervous system & 20 & $\begin{array}{c}265.7 \\
{[134.1-2738.4]}\end{array}$ & $\begin{array}{c}558.7 \\
{[289.2-968.4]}\end{array}$ & 310 & $\begin{array}{c}1256.4 \\
{[568.4-2489.0]}\end{array}$ & $\begin{array}{c}1083.2 \\
{[931.3-1251.9]}\end{array}$ \\
\hline Diseases of the respiratory system & 55 & $\begin{array}{c}612.0 \\
{[404.0-2921.0]}\end{array}$ & $\begin{array}{c}1536.3 \\
{[1055.2-2155.0]}\end{array}$ & 450 & $\begin{array}{c}733.2 \\
{[477.0-1400.9]}\end{array}$ & $\begin{array}{c}1572.3 \\
{[1388.0-1773.5]}\end{array}$ \\
\hline
\end{tabular}


Substance-related disorders

Suicide

Trauma (excluding suicide)

Other causes

$\begin{array}{cccc}- & - & - & - \\ 30 & 1516.6 & 838.0 & 25 \\ & {[741.4-4022.6]} & {[496.3-1318.7]} & 25 \\ 45 & 1948.1 & 1257.0 & 22 \\ & {[1047.2-4496.0]} & {[826.8-1825.2]} & \\ 55 & 2100.0 & 1534.2 & 22 \\ & {[1159.5-4662.8]} & {[1053.7-2151.9]} & \\ 15 & 238.2 & 419.0 & \\ & {[104.2-2733.8]} & {[192.6-786.7]} & \end{array}$

$\begin{array}{ccc}- & - & - \\ 25 & 1301.1 & 87.4 \\ & {[573.3-2598.3]} & {[48.9-143.3]} \\ 225 & 1473.1 & 786.3 \\ & {[728.6-2744.0]} & {[657.8-931.7]} \\ 225 & 876.4 & 786.2 \\ & {[497.5-1674.4]} & {[657.7-931.5]} \\ 80 & 290.3 & 629.0 \\ & {[206.4-889.0]} & {[514.8-760.2]}\end{array}$

Unknown causes

$\begin{array}{cc}238.2 & 419.0 \\ {[104.2-2733.8]} & {[192.6-786.7]}\end{array}$

(2) 


\section{A. Substance-related disorders}

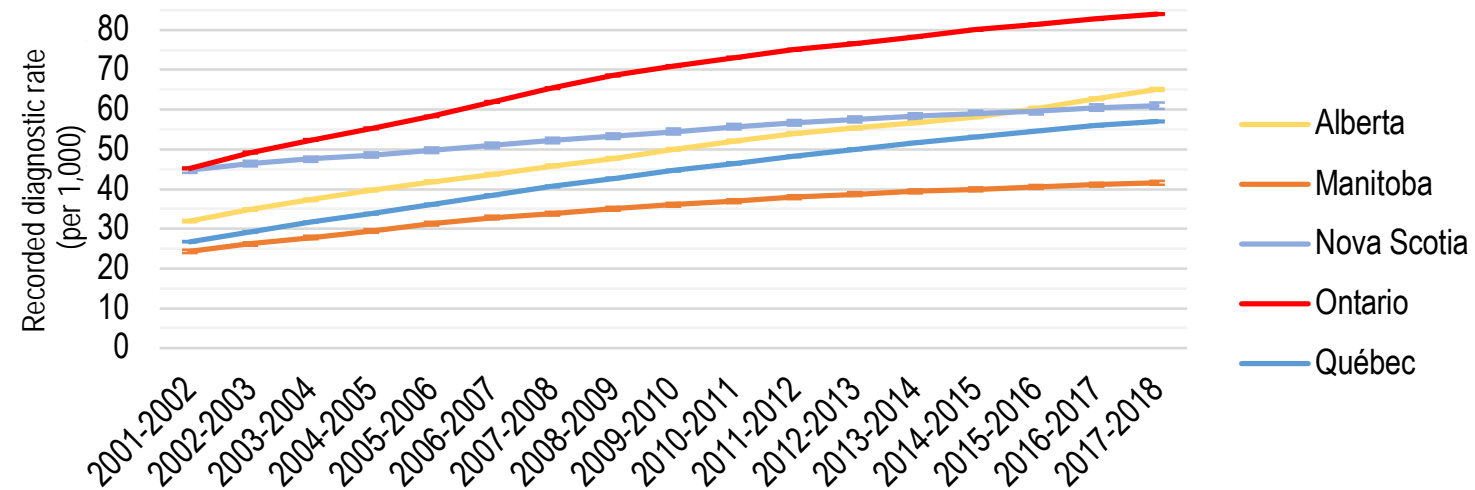

\section{B1. Alcohol-related disorders}
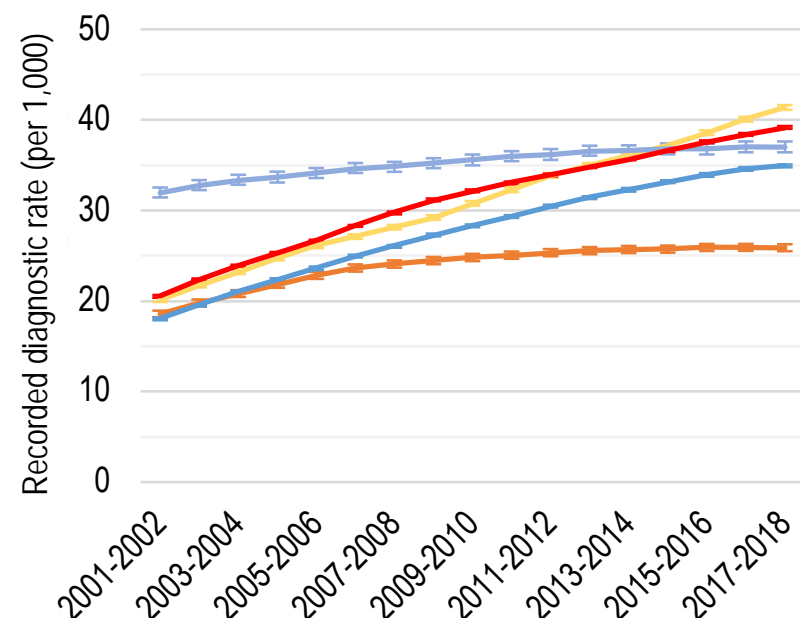

\section{C1. Drug-related disorders}

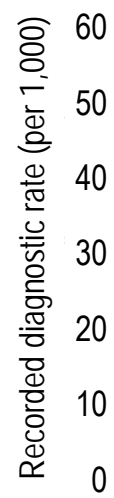

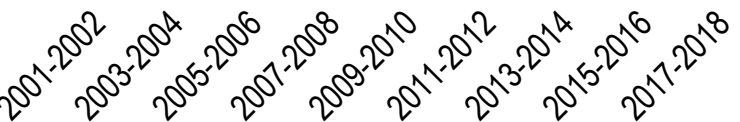

B2. Alcohol use disorders only
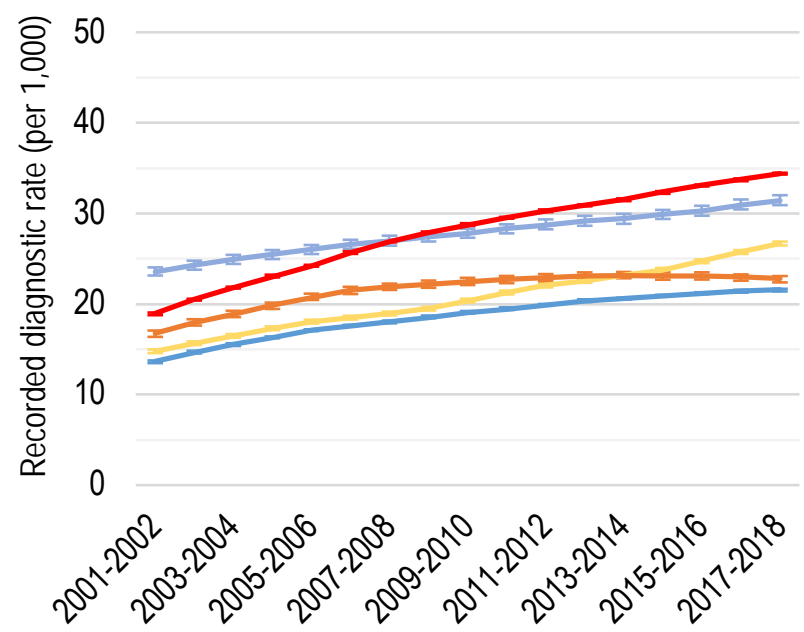

C2. Drug use disorders only
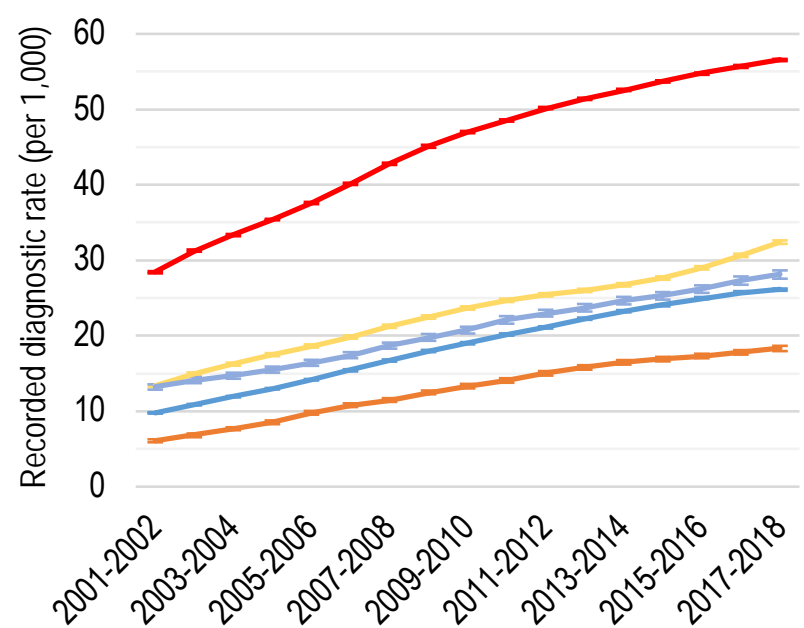


\section{A. Substance-related disorders}

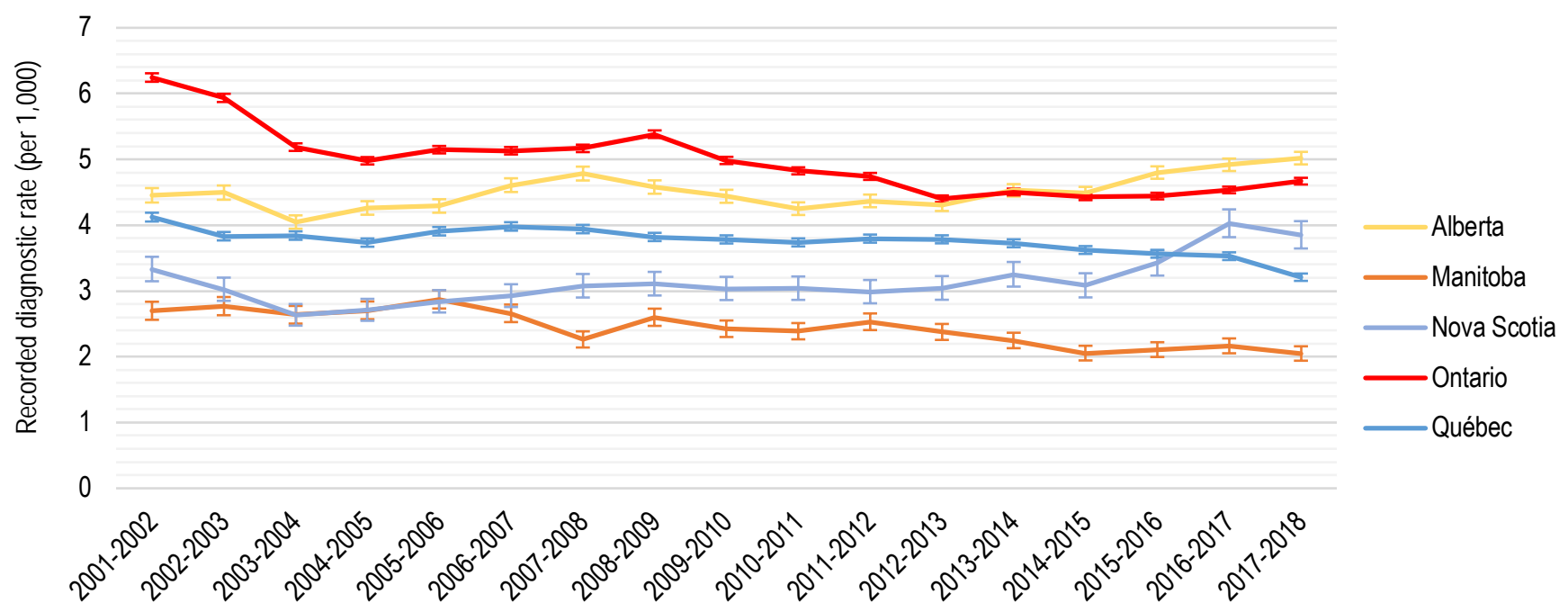

\section{B1. Alcohol-related disorders}

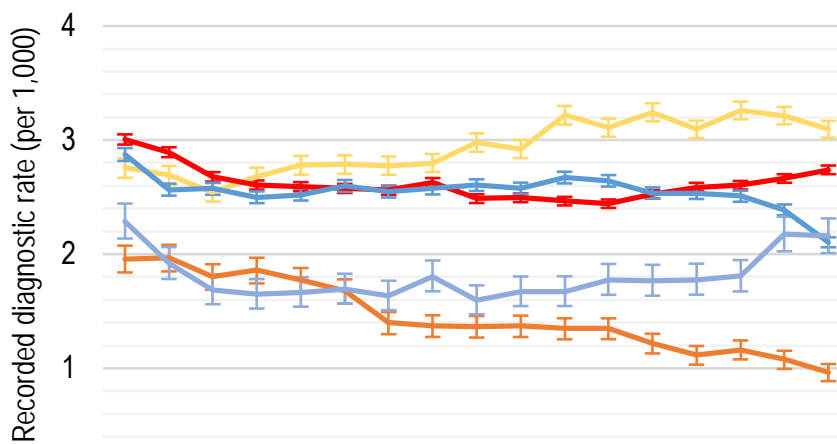

0

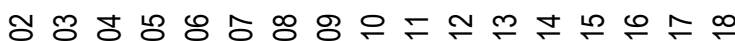

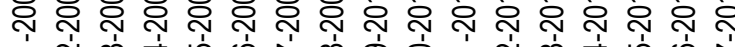

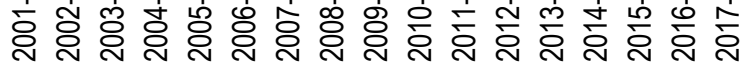

C1. Drug-related disorder

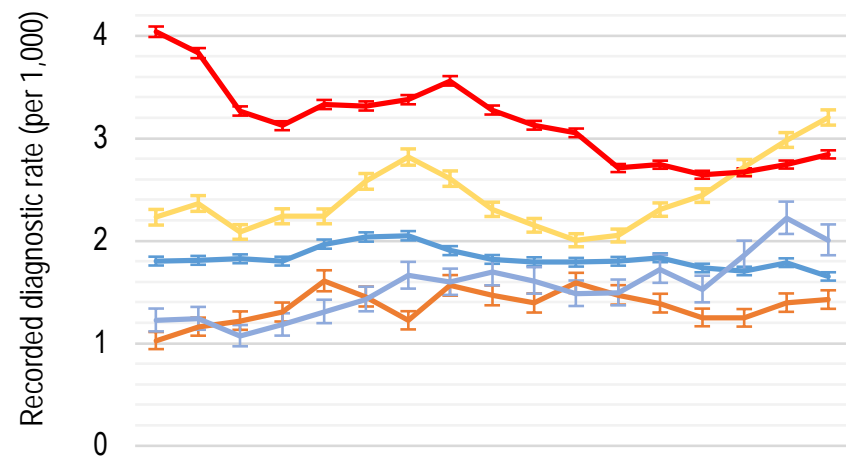

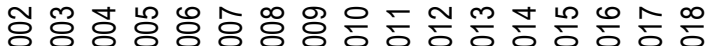

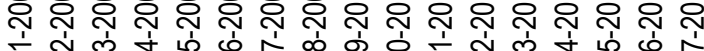

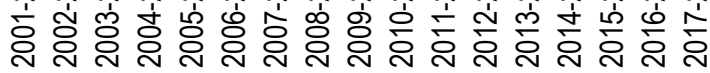

B2. Alcohol use disorders

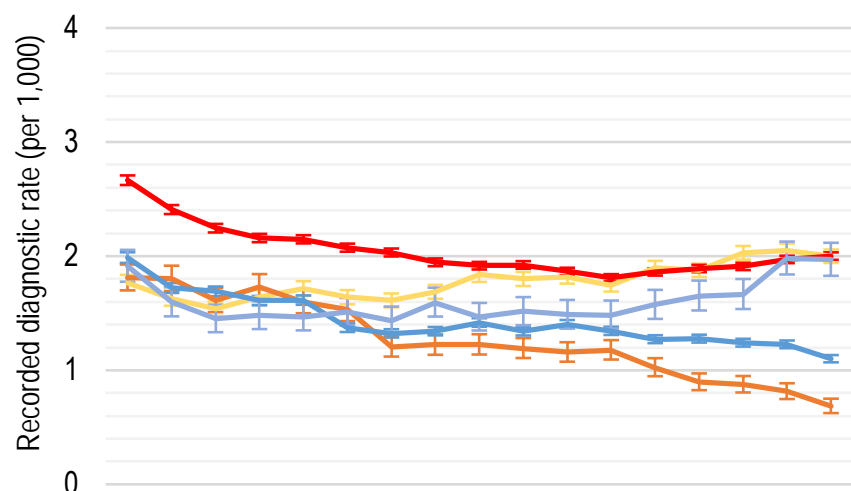

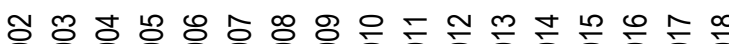

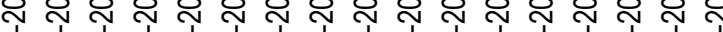

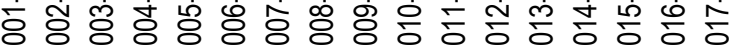

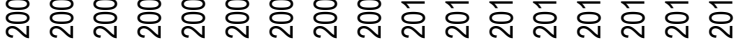

C2. Drug use disorders

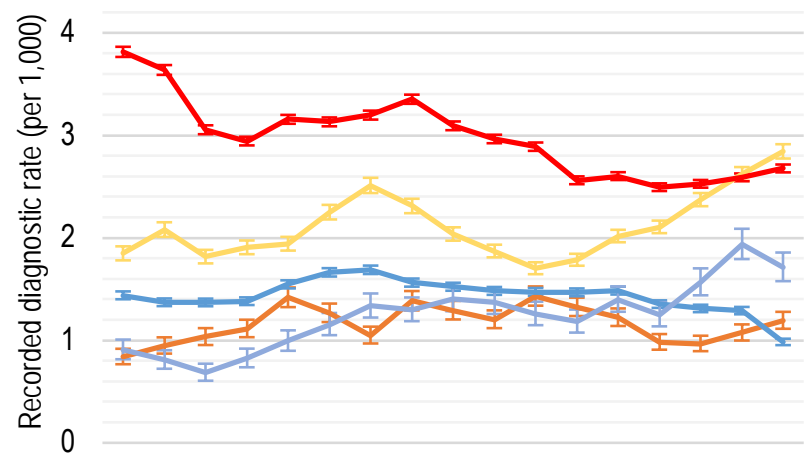

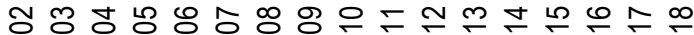

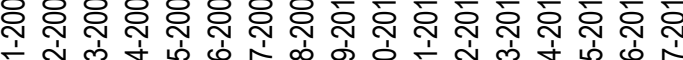
ธิ์ ช่ 穴 


\section{A. Substance-related disorders}

\section{5 \\ 30 \\ 20 \\ 15 \\ 10
5}
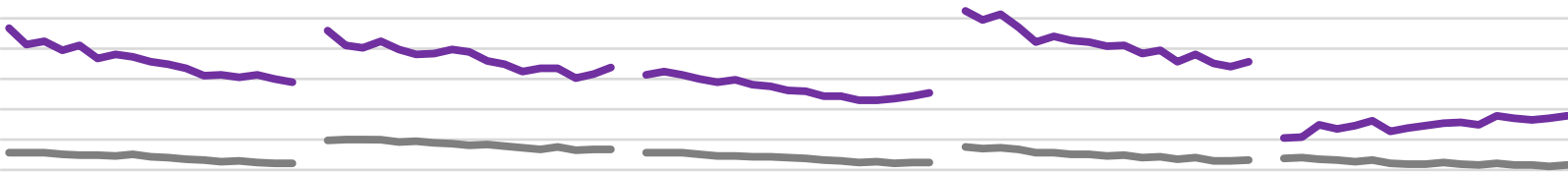

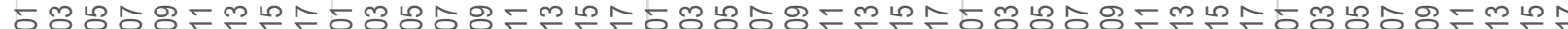

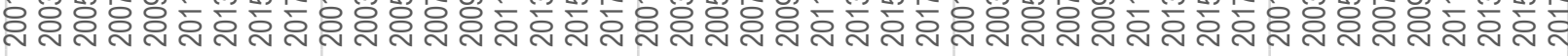
Alberta
Manitoba
Ontario
Québec
Nova Scotia

\section{B1. Alcohol-related disorders}

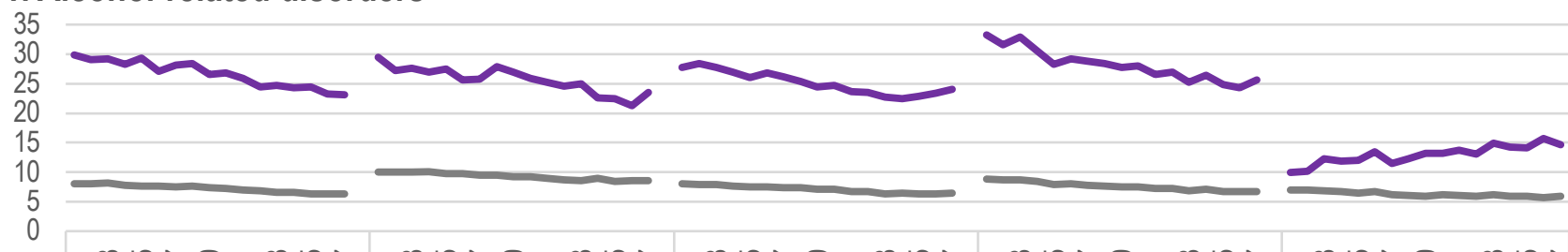

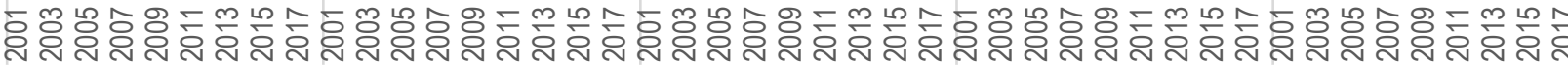
Alberta

Manitoba

Ontario

Québec

Nova Scotia

\section{B2. Alcohol use disorders}

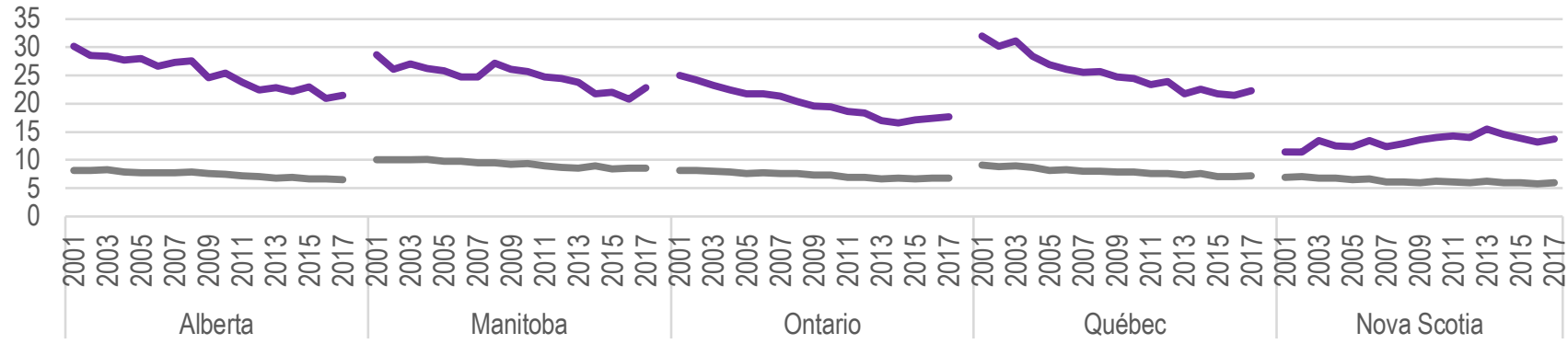

\section{C1. Drug-related disorders}

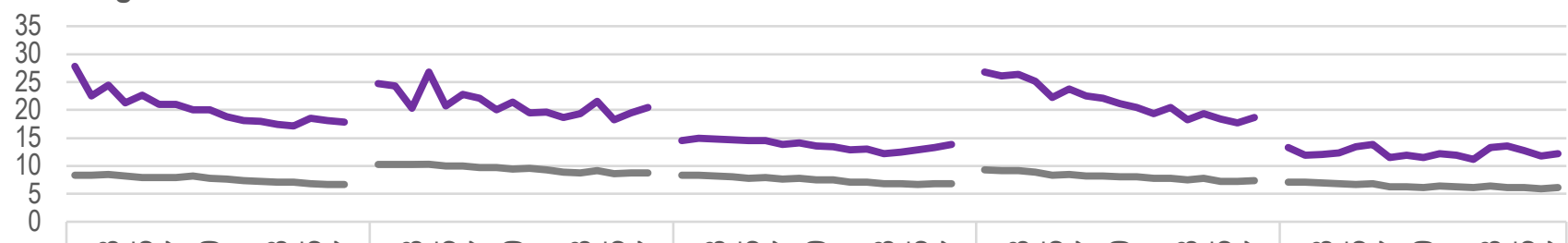

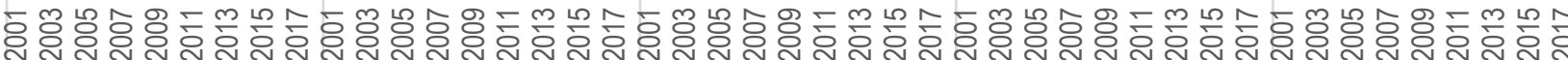

Alberta

Manitoba

C2. Drug use disorders

\section{5}

25

20

15

5

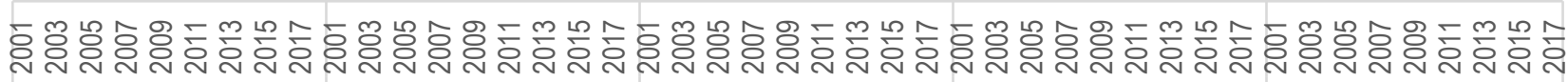
Alberta

Manitoba

Ontario

Québec

Nova Scotia 